\title{
CANADA'S POST 9/11 SECURITY ENVIRONMENT: THE STATE OF IMMIGRATION POLICY AND BORDER MANAGEMENT IN CANADA
}

\author{
by \\ Kristina Brugger, B.A., University of Western Ontario, 2008 \\ A Major Research Paper \\ presented to Ryerson University \\ in partial fulfillment of the requirements for the degree of \\ Master of Arts \\ in the Program of \\ Immigration and Settlement Studies
}

Toronto, Ontario, Canada, 2012

CKristina Brugger 2012 


\section{AUTHOR'S DECLARATION FOR ELECTRONIC SUBMISSION OF A MAJOR RESEARCH PAPER (MRP)}

I hereby declare that I am the sole author of this Major Research Paper. This is a true copy of the MRP, including any required final revisions, as accepted by my examiners. I authorize Ryerson University to lend this MRP to other institutions or individuals for the purpose of scholarly research. I further authorize Ryerson University to reproduce this MRP by photocopying or by other means, in total or in part, at the request of other institutions or individuals for the purpose of scholarly research. I understand that my MRP may be made electronically available to the public. 


\title{
CANADA'S POST 9/11 SECURITY ENVIRONMENT:
}

THE STATE OF IMMIGRATION POLICY AND BORDER MANAGEMENT IN CANADA

Kristina Brugger

Master of Arts, 2012

Immigration and Settlement Studies

Ryerson University

\begin{abstract}
In the post $9 / 11$ era the governments of Canada and the United States are faced with the challenge of enhancing national security while maintaining the flow of goods, services, and people. In addressing this matter, Canada has confronted some difficulty in the reformation of its security and immigration policies in attempting to strike a balance between meeting the demands of the United States, while also taking domestic considerations into account such as respect for human rights. Given the high levels of immigration seen in Canada, many believe that Canada is leaving itself open to cross border activities that pose threats to national security. As a result, it is questionable whether Canada's border management initiatives are properly equipped to combat threats to national security considering the effects high levels of immigration can have on border management efforts.
\end{abstract}

Key Words: Immigration; Border Management; National Security. 


\section{Acknowledgements}

I would like to thank my supervisor, Professor Arne Kislenko, for his guidance and support throughout the writing of my MRP. I would also like to my amazing family and close friends for their shoulders, love, support, and encouragement throughout this whole process. Without you this would not have been possible. 


\section{Table of Contents}

Author's Declaration $\quad$ ii

Abstract iii

Acknowledgements iv

Introduction $\quad 1-3$

Research Intent and Background $\quad 1-3$

The Case for Human Rights over Security: An Overview $\quad 3-7$

The Evolution of Immigration and Refugee Policy in Canada $\quad 7-19$

Immigration Act of $1952 \quad 7-8$

Equality and Non-Discrimination: 1960s - 1970s and the Trudeau Era $\quad 8-10$

$\begin{array}{lr}\text { Immigration Policy of the 90s } & 11-12\end{array}$

Immigration Policy for the New Millennium $12-19$

$\begin{array}{lr}\text { A New Canadian Security Environment } & 19-27\end{array}$

$\begin{array}{lr}\text { The Canada Border Services Agency } & 21-24\end{array}$

The Anti-Terrorism Act $\quad 24-26$

Canada's National Security Framework $\quad 26-27$

Immigration and Threats to National Security: Where's the Link? $\quad 27-30$

Issues in Canada's Ability to Manage Threat $\quad 30-40$

Jurisdictional and Mandate Overlaps and Other Issues in the Anti-Terrorism Act $\quad 30-34$

The Refugee Determination System and the IRB $34-38$

Issues in the CBSA $\quad 38-40$

Room for Improvement? Thoughts for the Future $\quad 40-45$

$\begin{array}{lr}\text { Concluding Remarks } & 45-46\end{array}$

Bibliography $\quad 47-51$

Glossary of Terms $\quad 52$ 


\section{Introduction}

Throughout its history, Canada has strived with some evident success to create and maintain the image of an immigrant-friendly nation. Canada has the highest rate of immigration per capita of any industrialized country in the modern world and is praised for its openness and accommodation of difference. However, since the events of September 11, 2001, issues with immigration and border management have highlighted potential risks to national security and caused Canada to revaluate its priorities. A major catalyst for this revaluation is the way that the relationship between Canada and the United States changed significantly because of the American perception that Canada's immigration and refugee systems are fragile due to high levels of immigration and inefficient border control measures. Over the last ten years much emphasis has been placed on the prevention of national security threats and, invariably, some observers point out that immigration and security have become inseparably linked in North America. In the post 9/11 era the governments of Canada and the United States are faced with the challenge of enhancing national security while maintaining the flow of goods, services, and people. In addressing this matter, Canada has confronted some difficulty in the reformation of its security and immigration policies in attempting to strike a balance between meeting the demands of the United States, while also taking domestic considerations into account such as respect for human rights. Given the high levels of immigration seen in Canada, many believe that Canada is leaving itself open to cross border activities that pose threats to national security. As a result, it is questionable whether Canada's border management initiatives are properly equipped to combat threats to national security considering the effects high levels of immigration can have on border management efforts.

\section{Research Intent and Background}

The purpose of this paper is to look at the state of immigration and border management in Canada taking into consideration the bearing immigration can have on border management efforts. Weaknesses in any system can be deep-rooted and traced to the policies that guide them, while others are superficial and easily corrected. What is obvious in the case of Canada is that principles of openness and multiculturalism are firmly rooted in many of Canada's 
immigration policies. It should be noted that for the purpose of this paper, immigration policy is defined as the policy of a state that governs the entrance and settlement of individuals in a country to which they are not native. Refugee policy falls under the umbrella term of immigration policy in a general sense, but it is acknowledged that in Canada immigration policy and refugee policy are distinctly different and deal with very different issues. Refugee policy deals with all individuals who claim to be a refugee as defined under the United Nations Conventions Related to the Status of Refugees as refugees, namely those seeking asylum in a foreign country from persecution on the basis of religion, race, political association, and the like in their country of origin. It should be noted that not everyone who claims refugee status is actually a genuine refugee which is why Canada has the refugee determination process and related polices in place. Immigration policy on the other hand deals with individuals who are seeking some form of resident status in a foreign country under clearly established categories such as family class or economic immigration. Border security policy is defined as measures taken by a government to monitor the transit of goods and people across its borders, which contributes to ensuring the protection of its land and population. Related to this, border management refers to the approach by border service agencies to enforce border security policy in order to manage the flow of trade, immigration, and travel at all ports of entry (i.e. air, land and water). These concepts are interconnected because border security agencies, such as the Canada Border Services Agency, are mandated to enforce aspects of immigration policies as well as border security policies. Although the immigration and border security systems are separate entities, they do operate jointly.

Canada prides itself on the idea of being an open, multicultural, and accepting society, and one that meets its international obligations in terms of refugee acceptance and human rights with vigour. However many argue that the immigration and refugee systems were designed to admit people on a much smaller scale than what has typically been the case over the last 40 years in Canada. The design of Canada's immigration system was practical in theory but may not be equip to deal with high levels of immigration. The unfortunate reality is that high levels immigration can have the capacity to overwhelm border management efforts. Because of this, it has become necessary for security policies, and subsequently immigration policies, to be 
adaptable and evolving in the same way that threats to national security are ever changing. If effective policies are in place border management systems have the capacity to operate effectively. Canada's policies and procedures to protect national security have been amended in recent history, but arguably not in a way that reflects awareness and understanding of Canada's security concerns and interests. As a result, the border management system may not be functioning with the effectiveness that is required to ensure the protection of Canada's national security. The presence of a variety of threats to national security in Canada, namely terrorist cells and organized criminal networks, exemplifies these issues. At the heart of the issue is the ability of these groups to enter Canada and operate within its borders. Many argue that this is the result of Canada's inability to manage its borders and its allegedly failing immigration system. The immigration system has been deemed to be failing because of the link between immigration and the presence and prominence of criminal and terrorist groups such as the Liberation Tigers of Tamil in Canada. It should be noted that threats to national security are not phenomena resulting exclusively from immigration. Canada and other nations have witnessed the recent advent of "home-grown" or domestic terrorism seen in groups like the Toronto 18. Many organized crime networks have originated domestically as well, with little or no connection to immigration. However, it cannot be denied that many individuals and groups will take advantage of opportunities to enter Canada through the immigration system, especially via the refugee determination system, because it is evident that border management has proved to be ill-functioning in the past.

\section{The Case for Human Rights over Security: An Overview}

When discussing immigration and border management, the question of human rights plays a pivotal role. Although human rights are not discussed at great lengths in this paper, it is important to highlight some key arguments. There is a body of literature that voices concern over the strengthening of border management because of the impact it can have on the civil liberties/human rights (terms used interchangeably throughout) of Canadian citizens, immigrants, and refugee claimants. Much of the literature argues that "more rights mean less 
security and more security means less rights" ${ }^{1}$. One core issue highlighted is that border management and immigration legislation introduced and revised since 2001 serves to reinforce racial classification and subsequently creates societal anxiety towards immigrants and refugees. Furthermore, these reforms contradict Canada's promotion of the integration of immigrants, and instead serve to alienate immigrant communities, creating a sense of exclusion ${ }^{2}$. This can create a perception that immigrant communities present an external threat to Canadian society, serving to justify exclusionary immigration and border management policies and practices to the wider public. Although explicit racism has been removed from immigration policy, less explicit forms of racism persist ${ }^{3}$. Distrust of refugees, heightened anxieties about crime and security, and more overt efforts to secure the border in the name of public safety contribute to societal anxieties toward immigration and promote tougher border management efforts. Many argue that this has resulted in the wrongful detention and deportation of many immigrants and refugees, and in some cases, has violated the rights and freedoms of individuals outlined under the Canadian Charter of Rights and Freedoms and some United Nations Agreements to which Canada is signatory. As such, nations that have moved to tighten border management efforts are in violation of numerous international treaties and, in the case of Canada, in violation of the Charter.

As a result of the overlap between border management initiatives and human rights concerns in Canada, the issue of enhanced security versus human rights has become a hot topic in public and political debate. There are several key areas where national security initiatives seem to have trumped the protection of human rights, not least of which is in the impact of increased cross-border intelligence sharing ${ }^{4}$. While cross-border intelligence sharing is a tool employed to enhance security and border management efforts in Canada, it also has the potential to erode certain human rights in relation to privacy and access to information. Increased cross-border intelligence sharing can mean less control over intelligence data for Canadian authorities,

\footnotetext{
${ }^{1}$ Wark, Wesley. 2006. National Security and Human Rights Concerns in Canada: A Survey of Eight Critical Issues in the Post-9/11 Environment. Ottawa: Canadian Human Rights Commission, 9.

${ }^{2}$ Keeble, Edna. 2005. "Immigration, civil liberties, and national/homeland security." International Journal Spring, Vol. 60, No. 2: 359-372.

${ }^{3}$ Pratt, Anna. 2005. Securing Borders Detention and Deportation in Canada. Vancouver: UBC Press, 44.

${ }^{4}$ Wark 2006, 6
} 
resulting in Canadian-generated information being handled under norms and practices that do not respect human rights. The fact that intelligence sharing means that Canadian authorities would be giving sensitive information to other nations with little or no control over how and when that information is used is a human rights issue ${ }^{5}$. Confronting issues of sharing intelligence with non-western allies who do not share western norms of human rights presents an array of issues including condoning repulsive and undemocratic legal systems and possible violations of international law ${ }^{6}$. Many point to the case of Maher Arar to substantiate these contentions. In 2002, upon a return trip to Canada from Tunisia, Arar, a Syrian-born Canadian citizen, was detained while on a stopover in New York. American officials detained him on the basis of misinformation allegedly received from Canadian intelligence officials indicating that Arar had links to terrorism. Arar was deported to Syria where he endured a year of torture before being returned to Canada. Concerns are also raised under the subject of cross-border intelligence sharing with regard to the construction of watch lists used to monitor cross-border travel. Other new intelligence gathering techniques, and the way that legal norms differ between western nations since September 11, 2001, are other matters of concern.

Border cooperation, including cross-border intelligence sharing, between Canada and the United States under agreements such as the Smart Border Declaration is another issue of contention. It has created speculation that increased border cooperation generates pressure to harmonize policies between Canada and the United States which could undermine Canada's autonomy as a nation ${ }^{7}$. In relation to this, the Safe Third Country Agreement and the ways that it changed the handling of refugee claims is a major issue in the discussion of human rights and security. The Safe Third Country Agreement came out of the Smart Border Declaration and amended the Immigration and Refugee Protection Act to state that individuals landing at the Canadian border from the U.S. to make refugee claims would no longer be eligible to do so. Human rights advocates argue that the Safe Third Country Agreement is a "bad deal" for refugees because the U.S. should not be considered a safe third country. This argument lies in the American practice of "extraordinary rendition" whereby individuals suspected of terrorism

\footnotetext{
${ }^{5}$ Wark 2006, 6

${ }^{6}$ Wark 2006, 33

${ }^{7}$ Keeble 2005, 361
} 
and criminality can be transferred to foreign jurisdictions for imprisonment and often interrogation through the use of torture (i.e. facilities in Guantanamo Bay) ${ }^{8}$.

Another piece of legislation under scrutiny by champions of human rights is the Anti Terrorism Act (ATA), which has been intensely debated because of the alleged oversight of human rights issues embodied in it. The ATA was quickly drafted and introduced in the immediate aftermath of September 11, 2001. Much scholarly and media attention was given to the ways that the ATA had the potential to negatively effect civil liberties in Canada ${ }^{9}$. Terrorism became a serious criminal offense for the first time in Canada but problems lay in the parameters of how terrorism was defined. Many argue that civil liberties were called into question because of the broad nature of the definition which allowed for people who do not pose a threat to national security to be classified as terrorists ${ }^{10}$. Another component of the ATA that was deemed to have the potential to lead to human rights abuses was the expansion of police powers. Under the ATA, preventative arrests were permitted where there were reasonable grounds to believe that terrorist activities would be carried out and that detention would deter terrorist activity from taking place ${ }^{11}$. Issues associated with racism, racial profiling, and discrimination were raised in relation to this clause. Many scholars further argue that the ATA took the position that the laws that protect the human rights and privacy of individuals hinder law enforcement efforts. To human rights activists this meant that the government was indeed choosing security over human rights ${ }^{12}$. The expansions of law enforcement powers to arrest, detain, and interrogate under the ATA seriously challenge the core pillars of civil liberties in Canada.

The issues that have been highlighted here are merely a few of the issues argued in opposition of stringent border management measures because of the potential to erode human rights. The maintenance of human rights is of the utmost importance, but in the new security environment that Canada is faced with, a delicate balance between respect for human rights and the

\footnotetext{
${ }^{8}$ Wark 2006, 6

9 Roach, Kent. 2007. Better Late Than Never? The Canadian Parliamentary Review of the Anti-terrorism Act. Montreal: Institute for Research on Public Policy, 3.

${ }^{10}$ Roach 2007, 5

${ }^{11}$ Roach 2007, 6

${ }^{12}$ Adelman, Howard. 2002. "Canadian Border and Immigration Post 9/11." The International Migration Review, 36:1: 15-28.
} 
protection of national security must be achieved. The goal of this analysis is to assess the state of immigration and border management initiatives in Canada and their ability to function successfully to manage threats to national security, given the impact that high levels of immigration can have on those initiatives. It should be noted that, irrespective of the arguments made forthwith, respect for human rights should be at the heart of all policies and initiatives regarding border management and immigration.

\section{The Evolution of Immigration, Refugee, and Border Security Policy in Canada}

The formation of immigration, refugee, and border security policies throughout Canada's history has largely been based on the ideas and interests of political leaders and key stakeholders. To give some theoretical basis to the creation of these policies in Canada, Ninette Kelley and Michael Trebilcock draw on the liberal theory of "Public Choice". More commonly applied to the functioning of private markets, the theory of "Public Choice" rests in the idea that the private market is driven by material self-interest. Similarly, the political process, and ultimately the policy making process, is driven by the self-interest of politicians, bureaucrats, voters, and interest groups. Key players vocalize and pursue their own self-interests in the policy making process ${ }^{13}$. Ultimately political players have the final say in the formation of policies and they will pursue the option that is most likely to best serve their self-interest, namely popular vote. The main interest of political players is to ensure support from voters and from the international community. Canada's pursuit of this interest can be seen throughout history in governmental motives for creating and amending immigration, refugee, and border security policies.

Immigration Act of 1952

The Immigration Act of 1952 came at a time when the international community was faced with repercussions from World War II. Millions of people were displaced throughout Europe and were in need of assistance. Canada's immigration system was a largely closed-off and selective

\footnotetext{
${ }^{13}$ Kelley, Ninette and Treilcock, Michael. 2010. The Making of the Mosaic A History of Canadian Immigration Policy. Toronto: University of Toronto Press, 7.
} 
in nature during this period. The Immigration Act of 1952 was the first new act since 1910, but it was similar to its predecessor in that it set out a framework within which the government was able to regulate its immigration priorities. It gave total discretionary power to the Minister Responsible for Immigration and gave the government the authority to limit admission on the basis of nationality, ethnic group, customs, class, and place of origin ${ }^{14}$. The Act went further to exclude other groups, such as homosexuals, drug addicts, and traffickers. Moreover, the tests for admissibility were expanded to include a literacy test that was expected to limit a large number of people. Canada's immigration policy remained limiting and racist in nature, which was a reflection of societal and political thinking of the times. In spite of this, strides were made in regards to refugee admittance. Nearly a quarter of a million refugees were admitted to Canada between 1946 and 1962, many of which came under the sponsorship of the government, Canadian citizens, and church groups, while others came under contract labour ${ }^{15}$. While a quarter of a million refugees may seem miniscule in relation to refugee intake today, it marked a move towards a more compassionate take on refugee policy and was also reflective of Canada's political interests at the time. The United Nations Convention Relating to the Status of Refugees was signed in 1951 and came into effect during this period. It is arguable that Canada, as a young, "up and coming" nation on the world stage, made these exceptions to gain recognition within the international community. It would have also drawn political support from special interest groups and citizens who were able to sponsor family members and other individuals to come to Canada from war-torn Europe. Major foundational changes related to opening Canadian society to mass immigration took place during the 1960s and 1970s and were largely the result of a shift toward more liberal thinking in society and in the political arena.

\section{Equality and Non-Discrimination: 1960s - 1970s and the Trudeau Era}

The early 1960s brought about a significant shift in societal and political interests with more focus on equality and non-discrimination. This subsequently resulted in policy shifts that

\footnotetext{
${ }^{14}$ Whitaker, Reg. 2004. "Immigration Policy" in The Oxford Companion to Canadian History Online, Edited by Hallowell, Gerald. London: Oxford University Press Reference Online. Accessed March 10, 2012. http://www.oxfordreference.com/views/ENTRY.html?subview=Main\&entry=t148.e774.

${ }^{15}$ Kelley and Trebilcock 2010, 344
} 
permitted increasingly high levels of immigration from non-traditional source countries ${ }^{16}$. Canada accepted on average 160,000 immigrants per year, amounting to a total of 2.25 million people during the period between the mid-1960s and 1970s. Faced with of high levels of immigration and no well-established system to deal with refugee admittance, Robert Andras (Minster of Manpower and Immigration at the time) commissioned a "Green Paper" to assess the problems with immigration in Canada and to develop an approach towards a new immigration act. The Green Paper was published in 1974 and was entitled A Report on Canadian Immigration and Population Study. It presented a negative perspective on the effects of immigration on Canadian society. It was argued that a rapidly changing and diverse ethnic demographic in Canada caused issues with urbanization and racial tensions ${ }^{17}$. The Green Paper concluded that immigration policy should be designed in direct relation to the needs of the labour market, and that legislation designating specific rural areas for immigrant populations to reside should be considered. Reactions to the Green Paper provoked widespread public and academic debate over the future of Canadian immigration policy. It also caused panic among the general public because the Green Paper seemed to blame immigration for issues that Canadian citizens were concerned with at the time. These issues included unemployment, economic recession, and housing shortages. In regard to refugee protocol, the Green Paper suggested that refugees should be considered under a separate category in the new immigration act but that the definition and admissibility of refugees should be left up to governmental discretion. It was suggested that the definition of a refugee under the United Nations should not be adopted as the definition in Canadian immigration policy. Ultimately the Joint Senate-House Committee rejected the findings in the Green Paper in 1975, stating that the economic, social, and cultural issues highlighted were not caused by immigration ${ }^{18}$. The findings of the Joint Senate-House Committee were reflective of the political thought of the government of the day, led by Pierre Elliot Trudeau. It was Trudeau who championed the ideas

\footnotetext{
${ }^{16}$ Whitaker 2004. Accessed March 10, 2012.

http://www.oxfordreference.com/views/ENTRY.html?subview=Main\&entry=t148.e774.

${ }^{17}$ Hawkins, Freda. 1975. "Canada's Green Paper on Immigration Policy." International Migration Review Vol. 9, No. 2: 237-249.

${ }^{18}$ Hawkins 1975, 238.
} 
of multiculturalism and diversity in Canada during his time as Prime Minister between 1968 and 1979, and again from 1980 to 1984.

The Immigration Act of 1952 was outdated and preceding initiatives to reform immigration policy had been minimal. In addition to the establishment of a task force to analyze policy and make recommendations for change, the government consulted with the provinces and the public by holding nation-wide hearings. These initiatives, and subsequent recommendations, formed the basis for the Immigration Act, 1976. The Immigration Act of 1976 is considered to be the cornerstone of the immigration system, setting out the fundamental principles and objectives found in Canadian immigration policies today. The principles and objectives included the promotion of diversity, family reunification, and the fulfillment of Canada's obligation under the United Nations Convention of 1951 and the United Nations Protocol Related to Refugees of 1967. Furthermore, the Immigration Act of 1976 sought to promote non-discrimination in immigration policy and cooperation between various levels of government and the nongovernmental sector to ensure the smooth resettlement of newcomers ${ }^{19}$. In consultation with the provinces, a provision for setting target numbers for various categories of immigrants was introduced. The new Act included four basic categories for eligibility for landed immigrant status (family class, humanitarian class, independent class, and assisted relatives class) and created a class for refugees to be admitted separately from immigrants. The definition of "refugee" adopted under the Act was that as defined under the 1951 United Nations Convention Relating to Refugees ${ }^{20}$. The "Points System" was also introduced in this Act. The Immigration Act of 1976 represented the most liberal and progressive measures taken by a government in Canada to date and received wide spread support from all parties in the House of Commons. The same support was received from the public, private stakeholders, interest groups, the media, and academics.

\footnotetext{
19 Citizenship and Immigration Canada (CIC). 2006. "Trail Blazing Initiatives Forging Our Legacy: Canadian Citizenship and Immigration, 1900-1977." Accessed March 11, 2012. http://www.cic.gc.ca/english/resources/publications/legacy/index.asp.

${ }^{20} \mathrm{CIC} 2006$
} 
Immigration Policy of the 90s

High levels of immigration were seen throughout the 1990s which was due to a Liberal dominated government and to more expansionary policies in the areas of family member sponsorship and business class immigrants. The 1990s was also highlighted by a dramatic increase in the number of refugees entering Canada. A new development was an influx in the number of refugees making claims from within Canada, including those made by people arriving at ports of entry, and by people who had been in Canada for long periods of time ${ }^{21}$. By the mid 1990s, more conservative commentators began to question the best way to deal with increasing levels of immigration and refugee claims in Canada, calling for major changes to the immigration system as a whole. Suggested changes included lowering the annual admission quotas, adopting more stringent selection criteria, and adopting a more restrictive approach to refugee policy.

Historically, restrictions to immigration and refugee policies often resulted from periods of economic downturn but this was not the case in the 1990s. The Canadian economy remained stable throughout much of that decade and into the early part of the new century. The need for change was rooted in major inconsistencies in the Immigration Act of 1976 that proved to be incapable of effectively managing immigration. After the publication of a report in 1994 entitled Into the 21st Century: A Strategy for Immigration and Citizenship, the government appointed a committee in 1996 to review the Immigration Act with the intention of completely overhauling it. The committee was specifically asked to look at ways to streamline the refugee process. The report issued by the committee, entitled Not Just Numbers: A Canadian Framework for Future Immigration, sparked major public debate and was criticized for its recommendations to move back to more restrictive policies. The recommendations included standard language testing for new immigrants, and a reduction in the power of the Immigration and Refugee Board to determine refugee status. This included a move to allow public servants to make these

\footnotetext{
${ }^{21}$ Whitaker 2004. Accessed March 10, 2012. http://www.oxfordreference.com/views/ENTRY.html?subview=Main\&entry=t148.e774
} 
decisions ${ }^{22}$. Other events also drew attention to the reality that the outdated Immigration Act of 1976 was in need of revisions. One such event was the arrival of 123 Chinese migrants by boat off the coast of British Columbia in 1999. The boat remained there for two months while an additional three ships arrived, bringing a total of 600 migrants from China's Fujian province to British Columbia assisted by smugglers paid up $\$ 40,000.00$ (US) to do so. Nearly all passengers from aboard these boats claimed refugee status and most did not show up for their claim hearings. Public scrutiny over the way that this and other situations were handled escalated. Criticisms surrounded many issues including, detention of refugee claimants, judicial hearings, processing and assessment of refugee claims and immigration applications, and the capabilities of immigration officers to manage the sheer volume of applications. Backlogs in the processing of both immigration applications and the assessment of refugee claims quickly built up and placed greater emphasis on the need to revise the Immigration Act of $1976^{23}$.

\section{Immigration Policy for the New Millennium}

With a firm mind-set in enhancing national security, Canada moved to revise its immigration policy with the creation of the Immigration and Refugee Protection Act (IRPA) in 2002. The IRPA reflected the same security interests found in other government policies and initiatives enacted during the period following September 11, 2001. The government characterized the Act as one designed to put a stop to abuse of the system, and prevent criminals and illegal immigrants from entering Canada. Many critics argued that the Act was largely skeletal and left the details to the bureaucracy to design and implement policy through regulation with little parliamentary oversight. The new Act also expanded the criteria for denying immigration applications and for restricting eligibility of refugee claimants. The grounds for removal and deportation were also expanded under the IRPA. Evidence of security concerns was further found in the expansion of the authority of immigration officials to detain immigrants and refugees that represent flight risk or danger to society and those whose identity is in doubt. The IRPA gave individual

\footnotetext{
${ }^{22}$ Immigration Legislative Review. 1998. Not Just Numbers: A Canadian Framework for Future Immigration. Ottawa: Government of Canada. Accessed March 10, 2012. http://www.chba.ca/uploads/Policy\%20Archive/1998/1998-02-28.pdf.

${ }^{23}$ Gallagher, Stephen. 2004. "Canada's Dysfunctional Refugee Determination System." Public Policy Sources No. 78: 3-39.
} 
immigration officials total discretionary authority to make decisions to detain people which was a power previously limited to higher level immigration officials.

A key component to the immigration system in Canada, and one that links security and immigration agencies in border management efforts is the Immigration and Refugee Board (IRB). Although the IRB was created in 1989, it is important to discuss it in a $21^{\text {st }}$ century context as it is at the heart of the refugee system and has come under intense scrutiny over the last decade for its lack of security discourse. Furthermore, the IRB's mandate and procedures underwent changes as a result of the IRPA. The IRB is an independent, quasi-judicial administrative tribunal. The chief executive officer or chairperson of the IRB reports to Parliament through the Minister of Citizenship and Immigration. The mandate of the IRB is to make "well-reasoned decisions on immigration and refugee matters, efficiently, fairly, and in accordance with the law" and to contribute to national security in Canada by ensuring the integrity of the immigration and refugee systems ${ }^{24}$. The members of the IRB are charged with deciding who needs refugee protection based on the guidelines provided under the IRPA. Citizenship and Immigration Canada ( $\mathrm{CIC}$ ) has the overall responsibility for immigration and refugee matters. CIC determines claims for refugee protection made abroad at Canadian embassies and consulates and is responsible for determining the eligibility of all refugee protection claims made in Canada. It is ultimately $\mathrm{CIC}$ who refers eligible claims to the IRB for a decision. Similarly, the Canada Border Services Agency (CBSA) is responsible for the enforcement of immigration and refugee matters and is involved in investigation, intelligence gathering, detention, and removal components of the refugee determination process. The CBSA will be discussed at greater length in subsequent sections.

The IRB itself is divided into four divisions, namely the Refugee Protection Division, the Refugee Appeal Division, the Immigration Division, and the Immigration Appeal Division. The Refugee Protection Division (RPD) determines whether a claimant present in Canada should be classified as a Convention refugee or a person in need of protection, as defined under IRPA, the Canadian Charter of Rights and Freedoms, the Convention Relating to the Status of Refugees, and the

\footnotetext{
${ }^{24}$ Citizenship and Immigration Canada (CIC). 2005. "You Asked About Immigration and Citizenship". Communications Branch. Accessed March 12, 2012. http://www.cic.gc.ca/english/pdf/pub/you-asked.pdf, 18.
} 
Convention against Torture ${ }^{25}$. A "Convention refugee" is defined as a person who is outside of their country of origin (most likely present in Canada) and is fearful of persecution on the basis of race, religion, nationality, political opinion, or membership in a particular group. To be deemed a Convention refugee an individual must be unable or unwilling to return to their country of origin because of this fear ${ }^{26}$. A person may be excluded from this definition if another democratic country has given them status and rights or if they have committed a war crime, crime against humanity, or other serious crime that is not politically motivated. A person in need of protection is someone who, if sent back to their country of origin, may face torture, cruel treatment and/or death in all parts of the country, and are unable or unwilling to seek protection from the authorities in that country. This is applicable so long as the potential torture, cruel treatment and/or death faced by the individual is unrelated to a legal case or caused by lack of adequate medical care in that nation. Initial decisions regarding refugee determination occur within this division. The RPD is meant to review and determine refugee claims "quickly and fairly" and in accordance with appropriate legislation. The RPD is mandated to make decisions that maintain the integrity of the refugee protection process and in the interest of protecting the safety and security of Canada and its citizens ${ }^{27}$. The IRB holds a hearing where claimants determined to be eligible for refugee status have the opportunity to present their case before a board member. The hearings are usually closed to the public in the interest of ensuring the safety of the claimant, but in some instances hearings are held publicly while the identity of the claimant is protected. This may be done in order for representatives of the United Nations High Commissioner for Refugees to observe the proceedings. All claimants are protected under the Canadian Charter of Rights and Freedoms and are entitled to health, legal, and social benefits upon arrival ${ }^{28}$. A member of the IRB oversees hearings with the assistance of a refugee protection officer who ensures that all available evidence is presented. This determination process can take up to two years to complete from the time of arrival.

\footnotetext{
${ }^{25} \mathrm{CIC} 2005,19$

${ }^{26} \mathrm{CIC} 2005,20$

${ }^{27} \mathrm{CIC} 2005,20$

${ }^{28}$ Stoffman, Daniel. 2002. Who Gets In: What's wrong with Canada's immigration program - and how to fix it. Toronto: MacFarlane Walter and Ross, 54.
} 
The Refugee Appeal Division (RAD), if utilized, is the process through which a claimant can appeal a decision handed down by the RPD. Claimants can appeal to the RAD to try and establish that the decision made at the RPD level was wrong by way of incorrect factual evidence, by law, or both. The RAD hearing is also an opportunity to introduction new evidence that may not have been previously available ${ }^{29}$. The appeal process is overseen by Governor in Council appointees (GIC) who are charged with a similar mandate as IRB members but are appointed by the Governor General of Canada. Decisions handed down from the RAD are expected to take up to 120 days unless a hearing is held, which only occurs in some exceptional cases. Failed claimants have the right to go beyond the RAD to appeal to the Federal Court of Canada should their claim be denied.

The IRB makes decisions related to appeals of inadmissibility rulings in refugee cases and in some immigration matters ${ }^{30}$. There are separate divisions to deal with immigration matters, namely the Immigration Division (ID) and the Immigration Appeals Division (IAD). The ID conducts hearings at the request of the Minster of Public Safety and Emergency Preparedness for permanent residents and other foreign nationals, either in Canada or abroad, who have been determined inadmissible. Much like decisions made through the RPD and the RAD, a member from within the ID conducts all hearings and a hearings officer is present to represent the Minister of Public Safety and Emergency Preparedness. Unlike, the RPD and RAD, the hearings are public unless a private hearing has been granted ${ }^{31}$. The individual who is under review has the right to representation by legal counsel, to have an interpreter if required, and to call witnesses. The hearing determines whether the individual meets the criteria to remain in Canada and if it is found that the person is in fact inadmissible, a removal order is handed down. In addition to reviewing appeals of immigration cases, the ID also reviews cases of individuals who have been detained under the IRPA. Reasons for detention include potential to pose danger to the public, uncertainty that the individual will appear for further immigration proceedings, and uncertainty about his or her identity. Immigration officials employed by the

\footnotetext{
${ }^{29} \mathrm{CIC} 2005,21$

30 Immigration and Refugee Board of Canada. 2011. "The Immigration and Refugee Board of Canada Does..." Last Modified November 17. Accessed June 4, 2012. http://www.irb-cisr.gc.ca/Eng/media/info/Pages/does.aspx.

${ }^{31} \mathrm{CIC} 2005,21$
} 
Canada Border Services Agency hold the authority to determine whether an individual fits any of the above criteria for detention.

The IAD is an independent tribunal and holds powers similar to the powers of a court. Individuals attempting to appeal to the IAD have the right to counsel. Both the Minister of Citizenship and Immigration and the Minister of Public Safety and Emergency Preparedness are represented during IAD hearing dependent on which ministry's decision is being appealed ${ }^{32}$. Canadian citizens and permanent residences that have sponsored family members whose applications have been denied by Citizenship and Immigration Canada can make appeals to the IAD. Appeals are also heard from permanent residence or foreign nationals who have received a deportation order from the Canada Border Service Agency and by foreign nationals who have not fulfilled their residency obligations. Additionally, the Minister of Public Safety and Emergency Preparedness can appeal a decision made by the ID. If an individual is found to be inadmissible on the basis of security concerns, or has been found guilty of criminality or violations of human rights, they are not eligible for appeal.

The IRB underwent significant changes when the IRPA was enacted in 2002. Specific to the current research undertaking are the changes regarding criminal justice. The IRPA introduced changes to the criteria for deportation as well as new restrictions on the right to appeal a decision to the Immigration Appeal Division (IAD) of the IRB ${ }^{33}$. Under the IRPA, people who are not citizens of Canada may be subjected to deportation if they are convicted of a criminal offence in Canada. The IRAP includes specific provisions for various classifications of immigrants and refugees who are convicted of criminal offences in Canada. For instance, under Section 36 (1) of the IRPA, permanent residents may be subject to deportation if convicted of a criminal offence in Canada that is potentially punishable by least 10 years imprisonment or six months for federal offences ${ }^{34}$. It should be noted however that deportation in these cases is not automatic and is subject to review by a representative of the Minister of Public Safety. This

\footnotetext{
${ }^{32} \mathrm{CIC} 2005,22$

${ }^{33} \mathrm{CIC} 2004$

${ }^{34}$ Canada. 2001. "Immigration and Refugee Protection Act" (Full Electronic PDF version). Last Amended March 13, 2012. Accessed June 7, 2012. http://laws-lois.justice.gc.ca/PDF/l-2.5.pdf, 23.
} 
representative has the power to refer cases to the Immigration Division of the IRB in order to have a removal order issued under Section 44 (2) of the IRPA ${ }^{35}$. The most important change regarding permanent residents and criminality is under Section 64 (2) of the IRPA, which took away their right to appeal deportation orders to the IAD if the sentence is at least two years. Permanent residents in these cases may still appeal for federal judicial review but this is limited to instances of legal or procedural error ${ }^{36}$. The hope here is that it will streamline the removal of permanent residents by eliminating the possibility of the IAD setting aside the removal decision on humanitarian and compassionate grounds. Further to this, permanent residents and protected persons who are under "stayed removal orders" (removal orders that have been issued but cannot be acted upon for a certain time period) for reasons of a criminal nature and are then convicted of a criminal offence can have their stay of removal cancelled under Section 62 (4) of the IRPA ${ }^{37}$. Similar provisions were put in place for foreign nationals under the IRPA. Foreign nationals are considered to be people other than Canadian citizens or permanent residents. Under the IRPA, foreign nationals who are convicted of a criminal offence in Canada, regardless of the sentence, may be subjected to deportation under Sections 36 (2) (a) and 36 (3) $(a)^{38}$. Foreign nationals do, however, have the right to appeal deportation orders to the IAD if they hold a permanent resident visa or have protected person status, which includes refugees. Any permanent resident and foreign national who has been convicted of an offence and sentenced to at least two years imprisonment is no longer eligible to have their refugee claim referred to the IRB for a hearing. These and other revisions made to immigration and refugee policies and processes, including the IRB, were done in the interest of enhancing border management efforts and security interests. However, the changes did not come without issues and did not address many pre-existing problems. These issues will be discussed at greater length in subsequent pages.

One of the major issues with the IRB, and consequently with border management, are the significant backlogs that exist within the refugee determination system. This issue will be

\footnotetext{
${ }^{35}$ Canada 2001, 24

${ }^{36} \mathrm{CIC} 2004$

${ }^{37}$ Canada 2001, 30.

${ }^{38}$ Canada 2001, 20.
} 
discussed at greater length, but many argue that these extensive backlogs have left the refugee system open to abuse. Recently, media reports have been discussing the Balanced Refugee Reform Act (BRRA), which is the latest government proposal, meant to improve security efforts in the immigration system by accelerating the processing of refugee claims thereby deterring abuse $^{39}$. The BRRA is meant to introduce faster decisions on refugee claims made by public servants in the Refugee Protection Division within the IRB. Under the new system it is expected that decision wait times will be reduced from 1,038 days to 45 days for claimants from "Designated Countries of Origin" and 216 days for claimants from all other countries. The BRRA would also introduce "Designated Countries of Origin" which is a list of countries that would not normally produce refugees. New criteria will be used in the identification of Designated Countries of Origin and remove the requirement to have them determined by an expert panel. This is proposed in the hope that it will deter people from using the refugee system to gain entrance into Canada because they would not be eligible under the regular immigration system.

Claimants who come from Designated Countries of Origin will still be entitled to a hearing under the IRB but hearings would be within 60 days. If a claim is denied, the claimant will still have the option to appeal but that appeal process will be expedited and held within 30 days. A new Refugee Appeal Division at the IRB would also be created which would be staffed by Governor in Council appointees. The intention is to accelerate the processing and decisionmaking time by reducing the timeline from 120 days to 90 days. Claimants from Designated Countries of Origin and individuals that have claims that have been determined to be unfounded would not have access to the new Refugee Appeal Division. Claimants who were subject to an exception in the Safe Third Country Agreement would also not have access ${ }^{40}$. This design is a measure to limit the number of appeal options for claimants. Furthermore, the government is also proposing changes to deportation methods. These tactics are designed to limit the options a failed claimant has to avoid deportation. One proposed measure is to defer access to Humanitarian and Compassionate consideration for one year. Other measures include

\footnotetext{
${ }^{39}$ Citizenship and Immigration Canada (CIC). 2012. "Backgrounder - Overview of Reforms to Canada's Refugee System." Last Modified February 16. Accessed March 13, 2012.

http://www.cic.gc.ca/english/department/media/backgrounders/2012/2012-02-16.asp

${ }^{40} \mathrm{CIC} 2012$
} 
possible regulations that would outline factors for consideration when a request to defer removal is received by the CBSA and deny automatic stay of removal for certain groups of failed refugees.

The Assisted Voluntary Return and Reintegration pilot program is also introduced in the BRRA which is meant to help remove low-risk failed refugee claimants more quickly ${ }^{41}$. This pilot program will be launched in the Greater Toronto Area and would include claimants from all countries when it begins, and then would be opened to claimants in the current system to try and expedite removals. There are also provisions to restrict a person who has committed a serious crime from making a refugee claim by amending current practice which denies a person access to the system if they have received a sentence of two years or more. The overall intention of these proposed provisions is to reduce the backlog in the refugee system. While the security based mentality has been fostering in the immigration and refugee systems, border management in Canada was simultaneously going through a similar overhaul.

\section{A New Canadian Security Environment}

Canada's management of the border and of immigration came under intense scrutiny in the wake of the terrorist attacks of September 11, 2001 and this period became a defining moment for many government policies in Canada. The relationship between Canada and the United States related to security and the border changed significantly and what was once the longest unguarded border in the world became a major security barrier ${ }^{42}$. Initial media accounts after the events of $9 / 11$ claimed that the individuals involved in the attacks had entered the United States from Canada. This forced the spotlight on Canadian border management and immigration and Canada came to be seen as the weak link in North American security efforts. It was argued that this was because of Canada's refusal to acknowledge the threat of terrorism ${ }^{43}$. Numerous scholars, political officials, and other interested parties have argued that border

\footnotetext{
${ }^{41} \mathrm{CIC} 2012$

${ }^{42}$ Aldeman 2002, 20

43 Bissett, James. 2008. "Security Threats in Immigration and Refugee Policies" in Immigration Policy and the Terrorist Threat in Canada and the United States edited by Alexander Moens and Martin Collacott, 75-95. Toronto: Fraser Institute, 76.
} 
management in Canada is flawed because it is the easiest country for foreign nationals to enter and gain permanent residency. Additionally it is argued that there is an absence of political debate regarding immigration and refugee policies resulting from Canada's desire to maintain its image as a "multicultural, tolerant and open" nation in an effort to gain political support ${ }^{44}$. Prior to September 11, 2001, Canadians did not think much about the border that divides Canada and the United States. With the implementation of the North American Free Trade Agreement (NAFTA) in 1994, the border became merely a regulatory gate and the question of security was something of a non-issue ${ }^{45}$. The Canada-United States Accord on Our Shared Border (1995) stated that the goals of the border were to promote international trade and the movement of people, reduce costs to both governments and the public, and provide protection against drug smuggling and the illegal movement of people. Very little attention was paid to the issue of border security and even when this accord was updated in 2000, only half a page was dedicated to security ${ }^{46}$.

Since 2001, the border has changed beyond recognition both physically and from a policy perspective, and many contend that this has come at a cost to Canada's sovereignty. Canada has always struggled with defining its self-interests as a result of competing nationalisms, regionalisms, and localisms and has also long dealt with the reality that its economy is highly dependent on trade with the United States ${ }^{47}$. On average a truck carrying goods crosses the border every three seconds ${ }^{48}$. Trade with the United States is worth approximately $\$ 1.8$ billion per day to the Canadian economy, making Canada the largest consumer of American goods, taking in approximating $25 \%$ of American exports. $85 \%$ of Canadian goods are exported to the United States and almost all American states consider Canada their number one export

\footnotetext{
${ }^{44}$ Gallagher, Stephen. 2008. "Canada's Broken Refugee Policy System." in Immigration Policy and the Terrorist Threat in Canada and the United States edited by Alexander Moens and Martin Collacott, 53-74. Toronto: Fraser Institute, 55.

${ }^{45}$ Drache, Daniel. 2004. Border Matter Homeland Security and the Search for North America. Halifax: Fernwood Publishing, xiii.

${ }^{46}$ Golovetskky, Basil. 2006. "Are Cross-Border Movements and Border Security Complements." Vancouver Centre for Excellence Research on Immigration and Integration in the Metropolis Working Paper Series No. 06-21, 4.

${ }^{47}$ Drache 2006, ix.

${ }^{48}$ Stoffman 2002, 75.
} 
destination ${ }^{49}$. In addition, approximately 200 million people cross the border every year for shopping and employment purposes. The economic impact of 9/11 was felt by both nations but Canada's economy would have taken the hardest hit had problems at the border persisted. After 9/11 wait times for transport trucks mounted to 15 hours or more at border crossings as a result of heightened security precautions and thorough inspections for potential threats and stowaways. Some Canadian assembly plants were forced to close down until the delays became less severe ${ }^{50}$. With threat to Canada's economy looming, Canada moved to tighten its security efforts to ensure the smooth flow of people and goods across the border. This meant harmonizing some immigration and border security policies with those of the United States in the interest of enhanced cross-border cooperation.

In response to growing concerns about the relationship between Canada and the U.S., Canada moved swiftly to pass various security based policies and initiatives that would satisfy mounting concerns about the state of its border security and mass immigration levels. This included the creation of a National Security Plan, a Threat Assessment Center, and four Integrated National Security Teams. In addition, Canada signed the Smart Borders Declaration with the U.S. in December of 2001, which set out an action plan for cross-border security cooperation. It also created the new Department of Public Safety and Emergency Preparedness (Public Safety Canada or PSC), which sought to better coordinate security agencies and improve information sharing ${ }^{51}$. It is the federal department that oversees emergency preparedness measures, crisis management, national security, corrections and policing, crime prevention, and border security services. PSC is at the heart of border management in Canada as it incorporates key security agencies such as the Royal Canadian Mounted Police (RCMP) and the Canada Border Services Agency (CBSA). It is acknowledged that the border management system in Canada is vast and complex, involving many agencies however the CBSA will be the focal point of discussion.

\footnotetext{
${ }^{49}$ Inge, Joseph R. and Findley, Eric A. 2006. "North American Defense and Security after 9/11". JFQ Forum Issue 40, 1st Quarter: 23-28.

${ }^{50}$ Stoffman 2002, 50.

${ }^{51}$ Kelley and Trebilcock 2010, 424.
} 


\section{The Canada Border Services Agency}

The CBSA is the frontline agency that is charged with assessing people and goods entering Canada at all ports of entry. It was created is 2003 as part of Public Safety and was designed to bring together all agencies involved in monitoring cross-border traffic. It now oversees all customs programs formerly managed by Canada Customs and Revenue Agency. CBSA also manages all immigration programs at ports of entry, and intelligence and enforcement programs which formerly fell under the jurisdiction of Citizenship and Immigration Canada. Additionally, it oversees all inspections at ports of entry previously conducted by the Canadian Food Inspection Agency ${ }^{52}$. The CBSA employs 13,000 individuals and more than half of those are frontline border officers who staff all land, air, and marine points of entry in Canada. It is also responsible for enforcing more the ninety different pieces of legislation, including the IRPA $^{53}$

In addition to holding responsibility over frontline security and enforcement at Canada's borders, the CBSA is involved with intelligence and risk management through several different initiatives. The National Risk Assessment Centre falls under the umbrella of the CBSA, which is an intelligence organization mandated to detect and prevent the movement of high-risk people and goods in Canada. The CBSA also houses the Immigration Intelligence Network (IIN), which is a central component to public safety and anti-terrorism efforts by facilitating legitimate travel through Canada's borders ${ }^{54}$. The IIN is involved with the collection and analysis of intelligence information regarding threats to immigration and refugee programs. The IIN also facilitates information sharing with CBSA's intelligence and law enforcement partners domestically and abroad. It is composed of three units including the National Head Quarters (NHQ) Immigration Intelligence Branch, Migration Integrity Officers employed at posts abroad, and Regional Immigration Intelligence units located throughout Canada. The NHQ is mandated to provide

\footnotetext{
${ }^{52}$ CIC 2005, 3

${ }^{53}$ Kislenko, Arne. 2010. "Guarding the Border: Intelligence and Law Enforcement in Canada's Immigration System" in The Oxford Handbook of National Security and Intelligence, edited by Loch, Johnson, 310-327. New York: Oxford University Press, 314.

${ }^{54}$ Canada Border Services Agency (CBSA). 2005. “Immigration Intelligence - Overview". Last Modified August 29. Accessed March 12, 2012. http://www.cbsa-asfc.gc.ca/media/facts-faits/031-eng.html.
} 
direction and case support on matters concerning suspected terrorists, war criminals, and individuals involved with organized crime by providing "intelligence-based" information to assist in decision-making on policies, programs, and individual cases ${ }^{55}$. Migration Integrity Officers are employed around the world and work with international partners to detect and prevent forms of irregular migration, including human trafficking, through initiatives such as the detection and interception of fraudulent travel documentation. Regional Immigration Intelligence units are spread throughout Canada and support field operations related to terrorism, organized crime, and irregular migration. The IIN is also responsible for assisting frontline immigration officers in determining the admissibility of individuals seeking to enter and remain in Canada.

The CBSA is responsible for frontline screening of immigrants, refugees, and visitors in order to prevent inadmissible individuals from entering and remaining in Canada. The CBSA is the agency responsible for investigations into immigration violations such as possible breaches of the IRPA and is involved with admissibility hearings undertaken by the Immigration Division of the IRB. Pre-removal risk assessments to determine if a person can be returned to their country of origin and the execution of deportation orders also fall under the jurisdiction of the CBSA ${ }^{56}$.

The CBSA is involved with a number of domestic and international partners to enhance border security through information sharing and other border security initiatives. One such initiative is the Integrated National Security Enforcement Teams (INSETs), which are comprised of representatives from the RCMP, the CBSA, the Canadian Security Intelligence Service (CSIS), and provincial and municipal police services. The purpose of INSETs is to facilitate the collection, analysis, and sharing of intelligence among domestic security agencies regarding individuals and organizations that pose a threat to national security. Through this, members of INSETs are better able to detect and track "criminal activities of terrorist groups" and individuals who pose a threat to national security ${ }^{57}$. The CBSA, along with other Canadian security enforcements

\footnotetext{
${ }^{55}$ CBSA 2005

${ }^{56}$ CBSA 2005

${ }^{57}$ Royal Canadian Mounted Police (RCMP). 2010. "Integrated National Security Enforcement Teams". Last Modified June 15. Accessed March 12, 2012. http://www.rcmp-grc.gc.ca/secur/insets-eisn-eng.htm
} 
agencies, is also involved with joint initiatives with U.S. agencies. The Integrated Border Enforcement Teams (IBETs) is one such initiative. IBETs are meant to enhance border security by identifying and investigating people and organizations that "pose a threat to national security or are engaged in other organized criminal activity" ${ }^{58}$. CBSA's role in IBETs is to jointly operate the initiative on the northern side of the border in conjunction with the RCMP. CBSA shares the responsibility of developing criminal intelligence to assist in investigations into cases of security threats and criminality. CBSA contributes information on immigration and customs related matters, assists with port of entry operations, and participates in joint risk assessments. Immigration contributions include support in areas of national security, organized crime, and irregular migration through the NHQ IIN, the regional IIN units, and overseas migration integrity officers $^{59}$. There are numerous components and layers to the CBSA which some see as a contributing issue to its inability to properly function to detect and intercept a broad range of national security threats. The operations of the CBSA and other border management agencies are guided by various policies and mandates handed down by the federal government. One of the most hotly contested security based legislations of this nature was the Anti-Terrorism Act, passed in the wake of $9 / 11$.

\section{The Anti-Terrorism Act}

The Anti-Terrorism Act (ATA) received Royal Assent in December 2001 and subsequently provided amendments to various Canadian laws and policies including the Canadian Criminal Code and the IRPA, both of which are legislation enforced by border management agencies like the CBSA and guide other institutions like the IRB. The ATA was introduced as part of Bill C-36 and had been quickly drafted in the wake of $9 / 11$. The federal government took the position that the speed with which the ATA was drafted and passed into law was necessary because of Security Council Resolution 1373, which required all nations to enact laws against terrorism by the end of $2001^{60}$. The ATA was designed to equip Canada with the tools necessary to hinder

\footnotetext{
${ }^{58}$ Canada Border Services Agency (CBSA). 2006. “Canada-United States Integrated Border Enforcement Teams". Last Modified August 25. Accessed March 12, 2012. http://www.cbsa-asfc.gc.ca/security-securite/ibet-eipfeng.html

${ }^{59}$ CBSA 2006

${ }^{60}$ Roach 2007, 4.
} 
terrorist organizations and activities through means such as defining terrorist activities and creating new terrorism related offences. These include, but are not limited to, facilitating a terrorist activity, and harbouring a person who is connected with or has the potential to commit terrorist activities ${ }^{61}$. It is referred to as "An act to amend the Criminal Code, the Official Secrets Act, the Canada Evidence Act, the Proceeds of Crime (Money Laundering) Act and other acts, and to enact measures respecting the registration of charities, in order to combat terrorism" ${ }^{62}$. The bill, in its original state in 2001, contains six major components. The first component sought to change the criminal code to include international terrorism conventions, to implement crimes related to terrorism and to provide means by which property owned or connected to terrorist cells can be seized. Second, the ATA created the Security of Information Act, which replaced the Official Secrets Act. The Security of Information Act sought to ward off threats of foreign espionage and terrorist organizations and to counter the gathering of unauthorized information. Third, amendments were made to the Canada Evidence Act by obliging parties in legal procedures to inform the Attorney General of any potential for release of sensitive information and information that could be damaging to "international relations, national defence or security". The fourth component created the Proceeds of Crime (Money Laundering) Act, which assists law enforcement and intelligence agencies in the detection and prevention of the financing of terrorist organizations and activities. The fifth component sought to strengthen the security system of the Canadian government and the final component of the ATA created the Charity Registration Act and amended the Canadian Income Tax Act. This was done to prevent people who provide financial support to terrorist organization and/or activities from benefiting from tax privileges granted to those who donate money to charity organizations $^{63}$. The ATA created robust debate regarding many of its provisions and subsequent reviews and committees were established to address the concerns. This mainly centered on the oversight of civil liberties in the act, which was discussed previously. Other debates surrounding powers of preventive arrests, investigative hearings, and the broad

\footnotetext{
${ }^{61}$ Crutcher, Nicole and Budak, Michelle. 2005. "The Anti-Terrorism Act and Security Measures in Canada: Public Views, Impacts and Travel Experiences. Justice Department Research and Statistics Division December rr05-11e, 3.

${ }^{62}$ Adelman 2002, 17.

${ }^{63}$ Adelman 2002, 18.
} 
definition of terrorism embodied in the ATA were also prevalent. However, other troubling aspects related to national security received little attention. Issues with overlapping jurisdictions and mandates of security and immigration agencies contained in the ATA, especially related to intelligence gathering and information-security, were largely overlooked in the debates. This will be discussed in subsequent sections.

\section{Canada's National Security Framework}

The government of Canada introduced its first ever national security strategic framework in April 2004 which was entitled Securing an Open Society: Canada's National Security Policy. It presented an action plan designed to address threats to security and articulated the core national security interests of Canada, namely "protecting Canada and Canadians at home and abroad, ensuring Canada is not a base for threats to its allies, and contributing to international security $^{\prime 64}$. The Canadian government was careful to stress that the design of the policy was done in a way that would strengthen the "open nature" of Canadian society. The policy furthered stated that the prosperity of Canada was directly linked to its openness towards immigration. This policy was not intended to interfere with Canada's values of democracy, respect for human rights, rule of law, and pluralism ${ }^{65}$. The intent was to deal with the new realities of security concerns and acknowledge that Canada's openness can cause tensions among communities. The major security concerns highlighted within the policy included terrorism, proliferation of weapons of mass destruction, failed and failing states, foreign espionage, natural disaster, critical infrastructure vulnerability, organized crime, and pandemics ${ }^{66}$.

New border security initiatives were introduced and outlined within the national security policy. The document stated that the key to national security lies in effective border management and the treatment of the border as an interception point to flush out threats. $A$

\footnotetext{
${ }^{64}$ Public Safety Canada. 2004. "Securing an Open Society: Canada's National Security Policy." National Library of Canada. Accessed March 12, 2012.

http://site.ebrary.com.ezproxy.lib.ryerson.ca/lib/oculryerson/docDetail.action?doclD=10083124, 1.

${ }^{65}$ Public Safety 2004, 2.

${ }^{66}$ Public Safety 2004, 7-8.
} 
modern border requires as much screening activity as possible to prevent high-risk travelers and cargo from entering Canada through air, land, and water ports. Initiatives included Smart Borders discussions with the U.S., and the Integrated Border Enforcement Teams, established in conjunction with Canadian and American border security agencies such as the Canada Border Services Agency and the U.S. Immigration and Customs Enforcement. Moving forward, the document outlines various domestic border security initiatives and the implementation of the Smart Borders Action Plan. Government spending towards these and other initiatives has amounted to approximately $\$ 92$ billion since 2001 however the breakdown of the spending is unclear $^{67}$. The Canadian government's intention to remain an open society while attempting to address its national security interests is consistently mentioned throughout its national security policy.

Canada's desire to maintain its image as an immigrant-friendly nation that strives for openness is evident throughout the development of many of the policies and initiatives discussed here. What is also evident, especially in the policies enacted since September 2001, is that Canada is struggling to strike a balance between this desire and its need to satisfy concerns from south of the border in order to maintain its economic stability. These competing interests have resulted in a complex system of border management that involves a variety of actors that is multidimensional, multi-layered and highly complicated. This brings to light many concerns over the capacity of the border management system to detect and deter threats to national security. Before discussing a selection of issues from both an immigration stand point and from a border security stand point, it is important to understand the link between immigration and threats to national security.

\section{Immigration and Threats to National Security: Where's the Link?}

It should be noted first and foremost that immigration is not the sole cause of threats to national security in Canada such as terrorism and transnational organized crime. As was previously discussed, homegrown terrorism and organized criminal networks that have their

\footnotetext{
${ }^{67}$ Fitzpatrick, Meagan. 2011. "Security spending after 9/11 tops \$92B." CBC News, September 7. Accessed March 12, 2012. http://www.cbc.ca/news/canada/story/2011/09/07/pol-911-security-spending.html.
} 
roots in Canada are present and are very serious threats to national security. However, there are links that can be made between immigration and threats to national security. In an interesting edited work entitled Evolving Transnational Threats and Border Security: A New Research Agenda, a number of scholars convincingly draw the connection between migration and national security concerns. Beginning with demographic changes, it is pointed out that population growth in the global south puts a major strain on the governments and economies of developing nations, often causing instability and fragility. The extent and depth of fragility of a state is a catalyst for migration ${ }^{68}$. Not only are fragile states a catalyst for migration they also tend to harbour terrorist and transnational organized crime networks because governments in those nations are weak and incapable of combating these threats within their own borders ${ }^{69}$. Since fragile states have come to be the top source countries of many newcomers in Canada, this notion is concerning. Many countries that are considered fragile states are also experiencing the "youth bulge" phenomenon, which occurs when the highest proportion of the population is between the ages of 15 and 29. This is most commonly seen in developing nations such as Afghanistan, Pakistan, the Democratic Republic of Congo, Iraq, Chad, Nigeria and Guatemala $^{70}$. It is argued that states with a youth bulge are more vulnerable to civil conflict because of the strain placed on education and economic systems, and high rates of unemployment or underemployment. Furthermore, people between the ages of 15 and 29 are the group most likely to migrate to the global north as they have the best chance for success in establishing themselves in a new country. This fact is true for Canada and can be seen in the 2006 Canada Census. Between 2001 and 2006 57.3\% of immigrants who arrived in Canada were between the ages of 25 to 54 and the second highest proportion of immigrants was found in people between the ages of 15 to $24^{71}$. This shows that there is a correlation between youthful populations, state fragility, and migration. As a result, migration has the potential to pose challenges to Canada's national security interests. More than half of Canada's immigrants

\footnotetext{
${ }^{68}$ Leuprecht, Christian. 2012. "Security Implication of Demographic Change" in Evolving Transnational Threats and Border Security: A New Research Agenda, edited by Christian Leuprecht et al., 39-50. Kingston: Center for International and Defense Policy, Queen's University, 40.

${ }^{69}$ Leuorecht 2012, 41

${ }^{70}$ Leuorecht 2012, 43.

71 Chui, Tina Tran and Kelly Maheux, Hélène. 2007. Immigration in Canada: A Portrait of the Foreign-born Population, 2006 Census. Ottawa: Statistics Canada, 13.
} 
originate from countries that are not democratic and that are fragile due to civil conflict and war. It is argued that this exposes Canada to transnational exploitation by ill-intentioned factions of Diaspora communities attempting to fuel conflict abroad ${ }^{72}$. This is not only a link between threats to national security and immigration but also a reason why it is essential for Canada to have a well-equipped border management system. The movement of people across Canada's borders is, in itself, a security concern when considering issues such as drug, arms, and human trafficking as well as transnational criminal activity, espionage, and terrorism that can originate in fragile states ${ }^{73}$. The number of people that enter Canada is huge in comparison to the number of concerning cases, however the link between immigration and security concerns cannot be denied.

An illustration on this can be drawn from the Liberation Tiger of Tamil Eelam (LTTE). The LTTE are a violent Sri Lankan-based terrorist organization formed in 1976 that seeks that establishment of an independent homeland for the Tamil minority in Sri Lanka ${ }^{74}$. Sri Lanka has been in a state of civil conflict for decades as a result of the struggle between the Sinhalese majority and the Tamil minority. The Canadian government listed the LTTE as a terrorist organization in April of $2006^{75}$. The LTTE was declared to be defeated in Sri Lanka in 2009 but activities and fundraising still continue within the Tamil Diaspora. Of the 400,000 Sri Lankan immigrants in Canada, many are ethnic Tamils who arrived as political refugees in the early 1980s, which coincides with the beginning of the civil war in Sri Lanka ${ }^{76}$. Canada has the largest population of Tamils outside of Sri Lanka and it is contended that the LTTE has established a firm presence in Canada through the large Tamil Diaspora ${ }^{77}$. The LTTE uses the Canadian Tamil Diaspora as a major fundraising source to finance its ongoing activities in Sri Lanka. It should be noted that here that what some, like the Canadian government, may interpret as a terrorist

\footnotetext{
72 Leuprecht 2012, 49.

${ }^{73}$ Crepeau, Francois. 2012. "Movement of Persons and Border Security" in Evolving Transnational Threats and Border Security: A New Research Agenda, edited by Christian Leuprecht et al., 51-57. Kingston: Center for International and Defense Policy, Queen's University.

74 Public Safety Canada. 2011. "Currently Listed Entities.” Last Modified August 24. Accessed August 7, 2012. http://www.publicsafety.gc.ca/prg/ns/le/cle-eng.aspx\#LTTE.

${ }^{75}$ Public Safety 2011.

${ }^{76}$ La, John. 2004. “Forced Remittance in Canada's Tamil Enclaves.” Peace Review 16:3: 379-385.

${ }^{77}$ La 2004, 379.
} 
organization could be viewed as an organization struggling for freedom. There is a significant grey area in defining which organizations, such as the LTTE, are terrorists and which are freedom fighters. This grey area can cause issues for practitioners of national security who are not trained to interpret this type of subjectivity.

\section{Issues in Canada's Ability to Manage Threat}

Canadian immigration and border security policies have been greatly influenced by the ideas and interests of political leaders and stakeholders during certain periods of time. During the earlier stages of the formation of immigration policies, Canada was focused on the selection of the "right" kind of immigrant and did so through the use of restrictive selection criteria and by allowing very few refugees into Canada. During the 1960 s and early 1970s, and in the midst of the design of the Immigration Act of 1976, desires for openness, inclusion, and multiculturalism were evident. The legislation created in 1976 was well intended but may not have been structured to manage high levels of immigration, which has subsequently caused major issues with border management. In the wake of September 11, Canada found itself attempting to strike an appropriate balance between its desires to remain an open society and meeting the needs of a new and more volatile security environment and there have been issues. Although Canada's immigration and border management systems were intensely scrutinized following 9/11, many argue that the weaknesses in Canada's system are over exaggerated myths. As a result Canada has come to be seen as a safe haven for criminals and terrorists when in fact this is not the case. In reality terrorist connections in Canada are few and far between, however the idea of Canada as the weak link in North American security continues to frame border security initiatives and changes to immigration policy ${ }^{78}$. These misperceptions and myths resulted in the strong, intense, and quick move toward security based policies following the events of 9/11. Some contend that the approach taken by the Canadian government to amend immigration and border management approaches was a "hammer to kill a fly" and that many of the changes that occurred were far more extreme than what was actually necessary. This was largely a

\footnotetext{
${ }^{78}$ Kislenko, 311.
} 
response to the mythology of Canada's weaknesses and has subsequently resulted in many issues in the immigration and border management systems.

One such issue is the problem of securitization, which affects many border management and immigration policies, and consequently the mandates of related agencies ${ }^{79}$. Securitization draws an enormous amount of resources towards many initiatives in general when resources could be better spent on fewer "at-risk situations" ${ }^{80}$. Furthermore, it has produced a border management system that it highly complicated and inhibits a number of issues, which call into question its effectiveness. Some issues with the ATA and policies in general, as well as with the IRB and the CBSA are discussed below to illustrate this argument.

\section{Jurisdictional and Mandate Overlaps and Other Issues in the Anti-Terrorism Act}

The issues with the ATA that are most publicly debated are those that relate to violations of human rights and to the definition of terrorism that was adopted in the Act. Other concerns that directly effect border management in Canada are less widely discussed. The ATA's provisions surrounding jurisdictions and mandates of various intelligence and security agencies are troubling. One of the main issues is the overlap of jurisdictions among certain agencies ${ }^{81}$. For example, the ATA adds provisions to the Proceed of Crime Act (PCA) implementing measures for the monitoring and suppression of the financing of terrorism. When the PCA was originally drafted the government of Canada created the Financial Transactions and Activities Tracking Centre (FINTRAC) and designated it responsible for the analysis of criminal financing. The ATA added the analysis of terrorism financing to FINTRAC's mandate and if information is found that poses threat to national security, FINTRAC must disclose this information to the Canadian Security Intelligence Service $(\mathrm{CSIS})^{82}$. This is a prime example of overlapping jurisdictions in the security and intelligence community, which causes major issues in the gathering of information. For one, it calls into questions which agency has the expertise to

\footnotetext{
${ }^{79}$ Crepeau 2012, 51.

${ }^{80}$ Crepeau 2012, 51.

${ }^{81}$ Wark, Wesley. 2002. "Intelligence Requirements and Anti-Terrorism Legislation” in Security of Freedom: Essay on Canada's Anti-Terrorism Bill edited by Ronald J. Daniels et al., 287-296. Toronto: University of Toronto Press, 289.

${ }^{82}$ Wark 2002, 292.
} 
analysis different types of information. In this instance it would be fair to assume that since FINTRAC was originally mandated to analyse information related to criminal and terrorist financing, that this information would be best left in the hand of that organization. It is also fair to assume that this type of overlap in jurisdiction can cause rifts among agencies that may be under-funded. It may also encourage competition for livelihood and additional funding instead of cooperation.

An additional jurisdictional issue exists in the form of division of mandates that may be better served if they were combined. To illustrate this, one may look at the relationship between the Communications Security Establishment (CSE) and CSIS. Under the ATA, the CSE was given new life. Traditionally the CSE was restricted to monitor, intercept, collect, and analyze foreign information and communications. The ATA added to this mandate giving the CSE authority to intercept Canadian communications if one end of the communications was coming from overseas $^{83}$. For example, if a transnational criminal organization located in Guatemala attempted to maintain communication with a cell in Toronto then CSE has the authority to intercept communications from both Canada and Guatemala. This mandate however overlaps with the mandate of CSIS, which is given authority over domestic security intelligence in Canada. The level of effectiveness of dividing security intelligence authority between two agencies remains to be seen but its troubling prospect to think how drastically the quality of security intelligence information would be effected if cooperation between CSE and CSIS fell apart. These jurisdictional issues within the intelligence community created under the ATA directly affect the ability to properly manage cross border flows in the interest of protecting national security. The security intelligence community has been thrust into a situation where too many agencies are involved in the oversight of certain initiatives and this can affect the quality of collection, analysis, and distribution of pertinent information used by agencies such as the IRB and the CBSA.

Jurisdiction and mandate overlaps are not something found exclusively under the ATA. In relation to border management agencies specifically, there is also distinct mandate and

\footnotetext{
${ }^{83}$ Wark 2002, 293.
} 
jurisdiction overlaps between CSIS and the CBSA in terms of intelligence collection and analysis. As stated above, CSIS is traditionally responsible for domestic security intelligence in Canada. It is the agency responsible for providing advance warning to partner departments and agencies of suspected activities that pose threats to national security. CBSA is mandated to collect and analyze security intelligence through its various branches (i.e. the Immigration Intelligence Network and the National Risk Assessment Centre) related to high risk cross-border activities. The overlap lies in the fact that CSIS also has a hand in immigrant security assessments. Under Sections 14 and 15 of the CSIS Act, CSIS is authorized to provide security assessments used in the review of citizenship and immigration applications for $\mathrm{ClC}^{84}$. The purpose of this is to identify and manage threats to security and to allow $\mathrm{CIC}$ to use the assessments to determine inadmissibility based on the criteria set out in the IRPA. CBSA also collects information through the Immigration Intelligence Network and through the National Risk Assessment Centre that is used in determining admissibility in immigration and refugee cases and to detect threats to national security in the immigration system. Much like the overlap between CSE and CSIS, the overlap between the CBSA and CSIS seems to be an oversight as the two agencies are essentially responsible for the same task. It would be a better and more effective decision to allow the CBSA to deal with all intelligence gathering and analysis related to immigration, freeing up CSIS to oversee other issues unrelated to immigration.

The information presented here is taken from a Toronto Star webpage dedicated to the story of the Toronto 18. The possibility of media biases is acknowledged but the information highlighted here is general and represents the most comprehensive account of the Toronto 18 case. In the summer of 2006 a group of young Muslim men were arrested for allegedly conspiring to launch a terrorist attack in Ottawa and downtown Toronto ${ }^{85}$. This case became the first instance in history were individuals were charged under the ATA for involvement in terrorist activities. The case of the Toronto 18 brought to light two troubling issues; it brought to light that terrorism is no longer a foreign produced phenomenon and that homegrown terrorism is an issue to be

\footnotetext{
${ }^{84}$ Canadian Security and Intelligence Service. 2005. "Backgrounder No. 1 - CSIS Mandate." Last Modified February 21. Accessed August 7, 2012. http://www.csis-scrs.gc.ca/nwsrm/bckgrndrs/bckgrndr01-eng.asp.

${ }^{85}$ Teotonio, Isabel. 2010. “Toronto 18." The Toronto Star. Last Modified December 1. Accessed July 4, 2012. http://www3.thestar.com/static/toronto18/index.html.
} 
taken seriously when considering Canadian national security interests. Secondly, it begged the questions of whether the ATA as a policy is in fact capable of deterring terrorism in Canada, whether plotted in Canada or abroad.

One of the inherent issues that lies in not just the ATA but in many of the policies and mandates of border security agencies is Canada's attempts to satisfy concerns from south of the border related to its border management and immigration. Many argue that this has resulted in a security environment that is attempting to mimic that in the U.S. without respecting Canada's domestic and international traditions. Canada has placed much emphasis on reforming its immigration and security policies through measures that are highly focused on terrorism prevention ${ }^{86}$. This is evident in the consistent focus on terrorism prevention in the design and language of Canada's national security policy:

"There is risk that the seeds of conflict and extremism can take root even in the most tolerant of settings. Canadians stand together in reaffirming that the use of violence to pursue political, religious or ideological goals is an affront to our values and must be met with a determined response by Canadians and by their government" 87 .

The very definition of terrorism is activities driven by political, religious and/or ideological goals with the intent to harm a society and its population ${ }^{88}$. The statement above can be interpreted to identify terrorism as its main security interest. Canada has been so fixated on terrorism that is has failed to place it in a rational list of other, and arguably more pressing threats to national security. Furthermore, the actual task of defining threats to national security is a difficult one. Threats to national security of all kinds are ever changing and what some might interpret as a threat to national security may not mean the same to others. Defining terrorism is a prime example of this. As states above, what defines terrorism to some groups actually represents a struggle for freedom or some other legitimate cause to others. The issue in defining threats to national security can present issues in policy and mandate formation because without clear conceptions of what constitutes a threat to national security, individuals who act to protect

\footnotetext{
${ }^{86}$ Roach, Kent. 2003. September 11 Consequences for Canada. Montreal: McGill-Queens University Press, 171.

${ }^{87}$ Public Safety 2004, 2.

${ }^{88}$ Interview with anonymous 1, March 8, 2012.
} 
national security cannot properly exercise their duties. Defining threats such as terrorism is easily done theoretically but it should not be left to individual practitioners who are trained to follow rules and identify threats based on lists to determine what a threat is in practice. There has been neglect in consideration of the need for general emergency preparedness in Canada, in terms of not only instances of terrorism but also instances of other threats such as organized crime and espionage. That being said, there are issues in both the border management system and the immigration system, specifically in refugee determination, that need to be addressed in order to better manage threats to national security entering Canada via its ports of entry. To illustrate this, issues with the IRB and the CBSA will be examined.

\section{The Refugee Determination System and the IRB}

The IRB has come under a great deal of scrutiny because several major issues that exist, many of which are arguably linked to unclear mandates and overlapping jurisdictions with other immigration and border management agencies. The IRB shares jurisdiction over refugee cases with many other agencies including Citizenship and Immigration Canada and the CBSA. Much like CSE and CSIS, agencies that are so intertwined have the potential to become ineffective because of confusing and unclear mandates and a lack of cooperation. The issues with the IRB may have as much to do with this as they do with the policies that guide and direct refugee determination. Although it is of the utmost importance for Canada to uphold its traditions towards respect for human rights, Canada has gone above and beyond what is required under international law when it comes to refugee determination and admittance. This has caused issues that many argue have made Canada vulnerable to national security threats.

Canada's track record of high rates of refugee acceptance is telling and has created a severe backlog within the IRB. In June 2008, IRB had a backlog in immigration cases of 950,000 cases and it was estimated that the number would rise to 1.5 million by 2012 . The refugee determination system had a backlog of 62,000 claims in 2008 and this was expected to rise to 84,000 within two years ${ }^{89}$. The government attempted to remedy this by amending the IRPA

\footnotetext{
${ }^{89}$ Bissett, James. 2009. "The Current State of Canadian Immigration Policy" in The Effects of Mass Immigration on Canadian Living Standards and Society, edited by Herbert Grubel, 3-28. Vancouver: The Fraser Institute.
} 
with Bill C-50, the Budget Implementation Act in 2008. The intention of this amendment was to give the government power to decide numbers and categories of immigrants and refugees admitted annually however the amendment did not apply to claims in the backlog. In spite of this amendment, a report issued by the Standing Committee on Citizenship and Immigration in 2012 indicates that earlier projections of backlog increases were in fact correct. More than a million immigration and refugee cases remain in the backlog as of February $2012^{90}$. With such extensive backlogs comes longer wait times for hearings and appeals before the IRB. Specific to the matter of refugee determination, anyone who makes a refugee claim in Canada is automatically entitled to a hearing before the IRB to determine eligibility, and claimants are entitled to free legal assistance throughout the process and this can take up to two years to complete $^{91}$. During the waiting period, claimants are entitled to social assistance, medical care, and other services, and are entitled to work in Canada. Even when a claim is found to be false, there are a number of appeals that can be made to determine whether or not a claimant has a case to be made on humanitarian or compassionate grounds. This means that time is on the side of the claimant and many argue that the longer a claimant remains in Canada, the less likely it is that he or she will be deported if all appeals fail. This is because Canadian authorities are unable or unwilling to follow through with the expensive and time-consuming process of deportation. As a result, thousands of people who make refugee claims, whether successful or not, remain in Canada making the refugee system an attractive option for entry for people with criminal intent ${ }^{92}$.

Another key weakness of the refugee determination system is the struggle to distinguish between genuine refugee claims and claims made by those who are abusing the system to avoid having to meet the normal requirements of the immigration system. There is no prescreening process to separate genuine refugee claims from false claims as there is in many

\footnotetext{
90 Tilson, David et al. "Cutting the Queue: Reducing Canada's Immigration Backlogs and Wait Times." Standing Committee on Citizenship and Immigration, February 2012. Accessed March 13, 2012. http://www.parl.gc.ca/Content/HOC/Committee/411/CIMM/Reports/RP5376198/411 CIMM Rpt02 PDF/411 Cl MM Rpt02-e.pdf.

${ }^{91}$ Bissett, James. 2010. "Abusing Canada's Generosity and Ignoring Genuine Refugees: An Analysis of Current and Still-needed Reforms to Canada's Refugee and Immigration System." Frontier Centre for Public Policy No. 96.

92 Bissett 2010, 26
} 
other western nations. This also brings to light that refugee claimants are rarely screened for criminality and security issues upon arrival at Canadian ports of entry, making Canada an attractive destination for human smugglers and international terrorist and criminal organizations $^{93}$. Since claimants are not detained upon arrival, they are asked to show up to hearings that often take place up to two years later and many do not appear. Since there is no means for tracking refugee claimants during the waiting period, the system is highly vulnerable to criminal infiltration ${ }^{94}$. The Toronto Star reported in 2008 that the CBSA had lost track of as many as 41, 000 individuals and most of those were believed to be failed refugee claimants ${ }^{95}$. While most refugee claimants that enter Canada pose no threat to national security, there is evidence to show that some do. The task of making criminal allegations against individuals is simple however it is much harder to substantiate those allegations. Some individuals involved in organized crime do not have prior criminal records. Furthermore, since many refugee claimants arrive in Canada with no documentation, it is often next to impossible to determine prior criminality ${ }^{96}$. Since all people who arrive on Canadian soil are automatically entitled to protection under the Canadian Charter of Rights and Freedoms and the rights provided under Canadian law, it is difficult to detain suspects for prolonged periods of time, leaving little choice but to release them regardless of evidence of criminality and of the risk this could pose to national security ${ }^{97}$.

One of the chief flaws in the refugee system is the IRB itself. Many argue that this is because it is staffed by under-trained officials whose individual political agendas may affect the outcome of the refugee cases they review. Peter Showler, Chair of the IRB in 2000, said that being a member of the IRB and handing down rulings is a very difficult and complex task ${ }^{98}$. The complexity stems from the fact that members of the IRB must have knowledge about social,

\footnotetext{
${ }^{93}$ Bissett 201027

${ }^{94}$ Bissett 2010, 27

95 Brennan, Richard. 2008. "41,000 illegal immigrants gone missing." The Toronto Star, May 7. Accessed March 13, 2012. http://www.thestar.com/news/canada/article/422383--41-000-illegal-immigrants-gone-missing

96 Bissett 2012, 31

97 Bissett 2010, 32

${ }^{98}$ Rousseau, Cecile et al. 2002. "The Complexity of Determining Refugeehood: A Multidisciplinary Analysis of the Decisions Making Process of the Canadian Immigration and Refugee Board". Journal of Refugee Studies Vol. 15 No.1: 43-70.
} 
political, and cultural environments of countries of origin, of legal issues, such as the definition of a refugee under international treaties, and how to judge evidence in quasi-judicial legal cases. A screening committee makes recommendations to the Cabinet to assist in the selection process, but it is the Cabinet that ultimately makes the appointments. The selection criteria are very general and background in immigration and refugee issues is not mandatory ${ }^{99}$. In spite of the fact that there is a training program for individuals selected as members of the IRB, many critics have called out questionable rulings made by the IRB that were attributed to the incompetence of its members. These questionable rulings are generally found in cases of individuals who held legitimate refugee claims but were denied status. Questionable rulings have also been made in cases of individuals who have been granted refugee status and have had known ties to terrorist and criminal organizations or had criminal backgrounds.

Another issue highlighted with the IRB is the mishandling and misinterpretation of evidence, cultural misunderstandings, and influence of personal political motives ${ }^{100}$. CBC News recently issued a news release discussing the inconsistent rates of approval among individual IRB members, stating that a claimant's likelihood of approval really depends on which IRB member hears the claim ${ }^{101}$. It is clear that there are major issues in the selection criteria of IRB members and in the training that is provided to new members, but this also calls into question the ability of IRB members to effectively cast aside personal motives when assessing cases. If Cabinet oversees the selection of IRB members, the influence of political agendas becomes an issue as some IRB members may be pushing the agenda of the government of the day. Many governments have promised to neutralize the IRB appointment process, but thus far none have moved to relinquish partisan control over the selection process ${ }^{102}$.

\footnotetext{
${ }^{99}$ Rousseau et al. 2002, 43

${ }^{100}$ Rousseau et al. 2002, 50-66

${ }^{101}$ Sheppard, Mary. "Refugee claims show inconsistent approval rates". CBC News, March 12, 2012. Accessed March 12, 2012. http://www.cbc.ca/news/canada/story/2012/03/12/refugee -claims-show-inconsistent-approvalrates.html

${ }^{102}$ Macklin, Audrey. 2009. "Refugee Roulette in the Canadian Casino" in Refugee Roulette Disparities in Asylum Adjudication and Proposals for Reform, edited by Ramji-Nogales, Jaya et al, 135-163. New York: New York University Press, 139
} 
Public Safety, as the overarching ministry in charge of national security and related agencies, lacks resources and the mandate to support the volume of security initiatives in general, and the effects of this are felt right through to border management agencies such as the CBSA ${ }^{103}$. Adding to the lack of resources is the focus on terrorism prevention in immigration and border management policies which cripples the ability of agencies such as the CBSA to broadly manage a wide range of potential threats passing through Canada's borders. As stated above, without a clear sense what of a threat to national security is in practice, CBSA officers are left to interpret threats based on government issued lists and rules they are made to follow which ultimately will effect the quality of the decisions made by those officers.

There are many issues in the enforcement of immigration and border policies, not least of which is with frontline CBSA officers. Much like those appointed to the IRB, some categories of employees of the CBSA have little or no background in matters of immigration and security ${ }^{104}$. The working environment on the frontlines of the CBSA also adds to the ineffectiveness of the agency as a whole. Incentives to perform well are not something offered by the CBSA. Promotion is generally based on theoretical knowledge during job competitions as opposed to practical experience and job performance. Furthermore, greater workloads are generally put on officers who perform well and this can discourage good work ethic among CBSA officers. These issues are in addition to the overall stress caused by shift work and low pay ${ }^{105}$.

Some argue that there are inadequacies in the training provided to CBSA officers. Training of CBSA officers is broken down into three phases, the first of which is only five weeks long. Entitled "CBSA Officer Induction Training Program", this phase of training is completed through distance learning, meaning it is a self-taught program with an instructor reachable only via the Internet. This phase of training is meant to increase knowledge of the CBSA, teach values and

\footnotetext{
${ }^{103}$ Sedra, Mark and Burt, Geoff. 2011. "Security Sector Reform (SSR) and the Domestic-International Security Nexus The Role of Public Safety Canada." The Centre for International Governance Innovation Special Report No.1, 5.

${ }^{104}$ Kislenko 2010, 317

${ }^{105}$ Kislenko, 2010317
} 
ethics, to create improved awareness of diversity and race relations, and to enhance understanding of how CBSA officers contribute to the overall success of the CBSA ${ }^{106}$. Whether these values are teachable through Internet-based, independent learning is questionable. The second phase of training is completed at the CBSA's main campus in Rigaud, Quebec and is designated as officer training and assessment in which candidates learn the basics of what is required to be a CBSA officer. Training is provided in primary and secondary inspection, policy interpretation, control and defensive tactics, firearms skills, and arrest and detention logistics. This phase takes place over the course of 18 weeks. The third phase of training is a placement at a port of entry to work with other CBSA officers ${ }^{107}$.

One of the issues with this training program is that it is heavily focused on customs as opposed to immigration and is not as in-depth as it potentially could be in providing the base knowledge needed to enforce immigration policies. There is nothing in the CBSA training program that provides officers with knowledge and understanding of international relations, and the social, political, and cultural environments of various countries of origin. One could argue that these are important factors to be considered in the decision-making process on the frontlines. The CBSA provides immigration intelligence that is shared with domestic and international partner agencies. Since there appears to be a disparity in the knowledge provided through training, the quality of the information that is being collected and shared through the CBSA may not be up to par. Furthermore, CBSA officers spend very little time with individuals crossing Canada's borders due to the sheer volume of people who enter Canada on a daily basis. Without appropriate training in immigration, refugee, and security issues, and other related topics essential to decision-making, it is arguable people are admitted into Canada on the basis of illinformed decisions made in the span of two or three minutes ${ }^{108}$.

The issues in the training of CBSA officers deepen the overarching issues with the border management in Canada and expand the potential for abuse of the system. If it is obvious that

\footnotetext{
${ }^{106}$ Canada Border Services Agency (CBSA). 2012. “Become a CBSA Officer”. Last Modified February 21. Accessed March 11, 2012. http://www.cbsa-asfc.gc.ca/job-emploi/bso-asf/training-formation-eng.html

${ }^{107}$ CBSA 2012

${ }^{108}$ Kislenko 2010, 318
} 
there is weakness in any government system, it can undermine the power and authority needed to ward off threats to security. With such fundamental operational issues in the CBSA and the IRB, and in the design and focus of governing legislation, it seems an impossible task for these agencies to effectively manage the border. The CBSA and the IRB are the frontline agencies that have the capacity to weed out security threats entering at Canada's borders. Without appropriately designed legislation to guide well-staffed agencies, Canada will remain open and exposed to threats to its national security.

\section{Room for Improvement? Thoughts for the Future}

The level of border security threats has not been unmanageable in Canada and the measures that have been taken thus far have been effective in managing some threats ${ }^{109}$. The cases of the Toronto 18 and the LTTE demonstrate that there are people in Canada who are capable of committing terrorist acts and that there are grounds to be concerned about terrorism. Instances of human trafficking, drug smuggling, and other organized crime activities indicates that this also poses a threat to security. Canada has reformed its immigration and security policies but what has resulted is a security environment that does not respect Canada's domestic and traditions and is not necessarily reflective of Canada's own national security concerns. Resources have been allocated to a very broad range of initiatives across the spectrum of immigration and border security agencies when it is arguably that it would be more useful to allocate resources to fewer, more specifically mandated initiatives that reflect Canada's own interests. During the confusion and panic that ensued followbing September 11, 2011 many agencies were created and/or broken down and reorganized with mandates that have jurisdictional overlaps, causing much confusion and great need for cooperation among agencies with little direction. These factors, in addition to a history of immigration that has resulted in severe case backlogs, are arguably leaving Canada's borders open to threats to national security.

There are several areas that Canada could look at to improve the management of the border and subsequently of security risks. This section ventures to suggest some potential options. It

\footnotetext{
${ }^{109}$ Interview with anonymous 1, March 8, 2012
} 
should be noted again that respect for human rights is of the utmost importance when assessing these issues and that a delicate balance must be maintained between border and immigration management efforts and respect for human rights. One of the biggest issues, as mentioned above, is the lack of screening measures available to assess individuals crossing into Canada. This is a contentious issue because many critics fear that the use of enhanced screening measures could infringe upon the human rights and freedoms of newcomers and Canadian citizens alike. The massive numbers of people who cross Canada's borders on a daily basis make it impossible to screen each individual who enters Canada. The reality is that most immigrants and refugees are not screened for criminality or security issues at all, which presents serious issues ${ }^{110}$. Canada's intelligence community is very small in comparison to that in other nations but there are agencies that are under funded that could serve a large role in providing immigration intelligence if granted the resources to do so. The Immigration Intelligence Branch of the CBSA is intended to better support screening efforts at the border and could be an excellent tool, if allocated proper financial and training resources. Although there is very little information available on the details of employment and funding of the Immigration Intelligence Branch, conclusions can be drawn from other information that is available. For example, of the 13,000 individuals employed at the CBSA more than half are frontline officers leaving a small pool of individuals who may be employed in the Immigration Intelligence Branch. Furthermore, Public Safety, as the overarching ministry that allocates funding to the CBSA, is lacking in resources so naturally this issue would also trickle down to effect access to resources and funding at $\mathrm{CBAS}^{111}$. Although it is unclear how much of the funding received by the CBSA is actually allocated to the Immigration and Intelligence Branch, the trickle down effect is a safe argument to conclude that the Immigration Intelligence Branch is under funded and under resourced. The government of Canada should look at investing more resources to ensure that the Immigration Intelligence Branch is capable of collecting and analyzing thorough immigration intelligence, which would increase overall screening capabilities and, by extension, border management efforts.

\footnotetext{
${ }^{110}$ Bissett, 2010, 27

${ }^{111}$ Sedra and Burt 2011, 6.
} 
As previous discussed, there are issues within the CBSA particularly with frontline CBSA officers. Recognizing these issues is the first step towards formulating resolutions, which is something the Canadian government has yet to do. First and foremost, the training program of prospective CBSA officers must be enhanced to increase knowledge of immigration and security issues. The CBSA should also include training to enhance understanding of not only legislation and law (international and domestic), but also of the social, political, and cultural environments of countries of origin. This would provide CBSA officers with a breadth of knowledge and understanding that would make the frontline decision-making process at the border more thorough and more effective. This would enhance the quality of intelligence information collected by the CBSA and shared with other partner agencies like the IRB.

Another area that is in need of a great deal of attention is the refugee determination system. The guiding legislation and functionality of the refugee determination system, specifically issues with the IRB, have come under intense scrutiny in relation to its assessment and tracking abilities. Canada's definition of a refugee is stretched beyond the parameters that are required under the United Nations Convention Related to the Status of Refugees ${ }^{112}$. According to the United Nations, a refugee is someone who fears being persecuted based on race, religion, nationality, and membership in a particular social or political group and is outside his/her country of origin, and is unwilling to seek protection in their home nation. Canada accepts this definition but goes a step further and allows anyone from any country to make a refugee claim if they fear persecution. The problem with this lies in the definition of country of origin. Some refugee claimants come from countries that share Canada's democratic values and are signatory to the United Nations Convention related to the Status of Refugees ${ }^{113}$. What this means is that Canada will accept claims from individuals who are originating from nations where there may not be well founded reason to fear persecution and therefore should not be considered genuine refugees. Critics have argued that this is one of the main reasons that Canada's refugee system is open to abuse and criminality. Designated safe countries, meaning countries deemed to be democratic and to have a track record of respecting human rights, are

\footnotetext{
${ }^{112}$ Collacott 2006, 30.

${ }^{113}$ Bissett 2010, 25.
} 
typically not countries that would produce refugees. It has been pointed out by scholars that Canada is the only country in the world that will accept refugees from the United States. In fact Canada admitted 317 refugees from the U.S. in $2003^{114}$. People who come to Canada from democratic countries are often "asylum shopping", meaning they will go from country to country until they find a place with high acceptance rates and a good resettlement program. Canada needs to seriously consider this because, in all likelihood, individuals who do this are not actually in need of protection. Furthermore, deporting asylum shoppers back to a "safe third country" is an option and is condoned under international law. Since the refugee determination process appears to have become an attractive opportunity to evade the regular immigration system, a first step in better securing Canada's borders would be to scale back the definition of a refugee to include only those individuals who originate from a country where there are reasonable grounds to fear persecution (i.e. non-democratic governments, civil war, etc.).

Secondly, measures to track individuals who are waiting to appear before the IRB should be examined. Australia is known for its stringent immigration system, but its refugee program offers some options that Canada could investigate. In Australia, people seeking refugee status are required to apply for a protection visa, a process that takes 90 days to complete. An application is completed by the applicant, and is then reviewed by an immigration officer. The applicant is interviewed to verify the information included in the application. Health, character, and security checks are also carried out for each applicant. During the 90-day process, applicants are granted a temporary visa, which assists the Australian government in tracking refugees while they wait for a decision to be made ${ }^{115}$. Using a visa system similar to that in Australia would streamline the Canadian refugee determination process in a number of ways. Firstly, it could decrease application review times. It could also provide an opportunity for a more in-depth review of a claimant's background, including the opportunity to screen individuals for criminality. Additionally, a visa system would offer a means of tracking refugee

\footnotetext{
114 Collacott 2006, 32.

115 Department of Immigration and Citizenship. 2011. "Fact Sheet 60 - Australia's Refugee and Humanitarian Program". Last Modified November 2011. Accessed March 14, 2012. http://www.immi.gov.au/media/factsheets/60refugee.htm
} 
claimants, as they would be required to have a temporary visa during the time the refugee application is being processed. This could also serve to put an end to the severe backlog in the refugee system moving forward.

A redesigned training program for IRB members to include training in understanding the cultural, social, and political environments of countries of origin is also essential. Drawing on the Australian example again, immigration officials in Australia are required to have a graduate certificate that is obtained through the completion of a six-month course in which prospective officers learn migration law and practice, and cultural awareness. This is something that should be considered for both CBSA officers and IRB members. Additionally, the selection of IRB membership should be taken out of the political realm entirely and a non-partisan selection committee should be given discretionary powers to appoint IRB members based on their knowledge and experience of immigration and security issues. It is acknowledged that detention and other arguably unethical methods are also used in Australia in the refugee determination system and it is by no means suggested here that Canada should look at any methods used in other nations that would violate international human rights laws, rights granted under the Charter, or put Canada in a position that would compromise its values as a nation. It is suggested, however, that Canada consider some options that could be incorporated into its own system to ease issues with the immigration system and enhance border management.

An overarching issue that affects both policy and agency initiatives is the issue of jurisdictional overlap among immigration, intelligence, and border security agencies. As was discussed above, some key agencies such as the CBSA and CSIS have mandates and jurisdictions that overlap, especially in terms of intelligence collection and analysis. This calls into questions which agency actually has the appropriate expertise to analyze specific types of information and to make decisions in specific kinds cases. It is also fair to assume that this type of overlap in jurisdiction can cause rifts among agencies that may be under funded which could encourage competition for livelihood and additional funding ${ }^{116}$. This could consequently cause the breakdown of co-

\footnotetext{
${ }^{116}$ Wark 2002, 294.
} 
operational relationships needed for the success of these agencies. The division of mandates that may be better served if they were combined under one agency is also an issue. Again, the level of effectiveness in dividing authority between two or more agencies puts a lot of emphasis on cooperation between agencies as the determinate for the successful functionality of those agencies and their efforts. If cooperation among agencies is not smooth and fully active, jurisdiction and mandate overlaps will directly affect the ability of these agencies to properly manage cross border flows ${ }^{117}$. The division of mandates and overlapping of jurisdictions also creates the need for more administration, which is costly for a system that already appears to have its resources spread very thin. Canada would do well to review policies such as the ATA that have resulted in the reorganization of some agencies and the creation of new ones whose mandates and jurisdictions obviously overlap. If the government of Canada established fewer agencies with clearly defined and condensed mandates, it would increase border management capabilities across the board. Not only that, the government would be able to better focus its resource allocation to initiatives that better reflect Canada's own national security interests. The unfortunate reality is that the changes recommended above are not likely to be undertaken by a government on any side of the political spectrum in Canada. This has as much to do with the sensitivity of the issues surrounding security and immigration as it does with the sheer financial resources it would require to make these changes.

\section{Concluding Remarks}

The level of border security threats has not been unmanageable in Canada and the measures that have been taken by the government thus far have been relatively effective in managing threats $^{118}$. However issues still remain. The presence of criminal and terrorist organizations who have used the immigration system to gain entrance to Canada are a lingering reminder of these remaining issues. The manner that Canada has reformed its immigration and security policies has arguably resulted in a security environment that does not respect Canada's domestic and international traditions and is not necessarily reflective of Canada's own national security concerns. Canada's competing interests in attempting to satisfy American concerns

\footnotetext{
${ }^{117}$ Wark 2002, 295.

118 Interview with anonymous 1, March 8, 2012
} 
over the state of its immigration and border management and maintaining its national traditions has resulted in a complex system of border management that involves a variety of actors. Because of this, resources have been spread very thin across a broad range of border security and immigration initiatives and agencies when it is arguable that it would be more useful to allocate resources to fewer, more specifically focused initiatives that reflect Canada's own interests. Ultimately it is in the inclination of the government of the day to amend the immigration and border management systems in any way which it sees best suited to please its particular faction of voters. This has been true throughout Canada's history and the state of both systems is reflective of the values and interests of the current Canadian government. Previous governments have avoided even the discussion of moving toward security based policies in border management and immigration. However, the right wing approach and economic based ideals of the current Canadian government have created an environment in which it has become appropriate to take that step and the results are questionable.

Until Canada assesses the array of issues embodied in its border management and immigration initiatives and institutions, it will remain open to serious and evolving threats to its national security. Any attempts to remedy issues thus far have fallen just short of solving the core functionality issues of the border management system as a whole. Canada has work to do in terms of enhancing its knowledge of new and emerging security concerns and in creating policies that are clear and concise and are reflective of its own domestic and international interests. By doing so, Canada's border management system would be better equipped to detect and deter threats to national security and it would be better able to incorporate its core national values: democracy, rule of law, openness, diversity and respect for civil liberties. 


\section{Bibliography}

Note: Interviews were conducted in confidentiality, and the names of interviewees are withheld by mutual agreement. Interviewees are identified by number only but identities are known to the author and the MRP supervisor.

Adelman, Howard. 2002. "Canadian Border and Immigration Post 9/11", The International Migration Review, 36:1: 15-28.

Bissett, James. 2008. "Security Threats in Immigration and Refugee Policies" in Immigration Policy and the Terrorist Threat in Canada and the United States edited by Alexander Moens and Martin Collacott, 75-95. Toronto: Fraser Institute.

Bissett, James. 2009. "The Current State of Canadian Immigration Policy." In The Effects of Mass Immigration on Canadian Living Standards and Society, edited by Herbet Grubel, 3-28.

Vancouver: The Fraser Institute.

Bissett, James. 2010. "Abusing Canada's Generosity and Ignoring Genuine Refugees: An Analysis of Current and Still-needed Reforms to Canada's Refugee and Immigration System." Frontier Centre for Public Policy No. 96: 5-46.

Brennan, Richard. 2008. "41,000 illegal immigrants gone missing." The Toronto Star, May 7. Accessed March 13, 2012. http://www.thestar.com/news/canada/article/422383--41-000illegal-immigrants-gone-missing.

Canada. 2001. "Immigration and Refugee Protection Act" (Full Electronic PDF version). Last Amended March 13, 2012. Accessed June 7, 2012. http://laws-lois.justice.gc.ca/PDF/I-2.5.pdf

Canadian Security and Intelligence Service. 2005. "Backgrounder No. 1 - CSIS Mandate." Last Modified February 21. Accessed August 7, 2012. http://www.csisscrs.gc.ca/nwsrm/bckgrndrs/bckgrndr01-eng.asp

Canada Border Services Agency (CBSA). 2005. "Immigration Intelligence - Overview." Last Modified August 29. Accessed March 12, 2012. http://www.cbsa-asfc.gc.ca/media/factsfaits/031-eng.html.

Canada Border Services Agency (CBSA). 2006. "Canada-United States Integrated Border Enforcement Teams". Last Modified August 25. Accessed March 12, 2012. http://www.cbsaasfc.gc.ca/security-securite/ibet-eipf-eng.html.

Canada Border Services Agency (CBSA). 2012. "Become a CBSA Officer." Last Modified February 21. Accessed March 11, 2012. http://www.cbsa-asfc.gc.ca/job-emploi/bso-asf/trainingformation-eng.html. 
Chui, Tina Tran and Kelly Maheux, Hélène. 2007. Immigration in Canada: A Portrait of the Foreign-born Population, 2006 Census. Ottawa: Statistics Canada.

Citizenship and Immigration Canada (CIC). 2004. "Criminal Justice and the Immigration and Refugee Protection Act." Last Modified April 26. Accessed June 7, 2012. http://www.cic.gc.ca/english/resources/publications/justice.asp

Citizenship and Immigration Canada (CIC). 2005. "You Asked About Immigration and Citizenship." Communications Branch. Accessed March 12, 2012.

http://www.cic.gc.ca/english/pdf/pub/you-asked.pdf.

Citizenship and Immigration Canada (CIC). 2006. "Trail Blazing Initiatives Forging Our Legacy: Canadian Citizenship and Immigration, 1900-1977." Accessed March 11, 2012. http://www.cic.gc.ca/english/resources/publications/legacy/index.asp. Citizenship and Immigration Canada (CIC). 2012. "Backgrounder - Overview of Reforms to Canada's Refugee System." Last Modified February 16. Accessed March 13, 2012. http://www.cic.gc.ca/english/department/media/backgrounders/2012/2012-02-16.asp.

Crepeau, Francois. 2012. "Movement of Persons and Border Security" in Evolving Transnational Threats and Border Security: A New Research Agenda, edited by Christian Leuprecht et al., 3950. Kingston: Center for International and Defense Policy, Queen's University.

Crutcher, Nicole and Budak, Michelle. 2005. "The Anti-Terrorism Act and Security Measures in Canada: Public Views, Impacts and Travel Experiences. Justice Department Research and Statistics Division December rr05-11e.

Department of Immigration and Citizenship. 2011. "Fact Sheet 60 - Australia's Refugee and Humanitarian Program." Last Modified November 20. Accessed March 14, 2012. http://www.immi.gov.au/media/fact-sheets/60refugee.htm.

Drache, Daniel. 2004. Border Matter Homeland Security and the Search for North America. Halifax: Fernwood Publishing.

Fitzpatrick, Meagan. 2011. "Security spending after 9/11 tops \$92B." CBC News, September 7. Accessed March 12, 2012. http://www.cbc.ca/news/canada/story/2011/09/07/pol-911security-spending.html.

Gallagher, Stephen. 2004. "Canada's Dysfunctional Refugee Determination System." Public Policy Sources No. 78: 3 - 39. 
Gallagher, Stephen. 2008. "Canada's Broken Refugee Policy System." in Immigration Policy and the Terrorist Threat in Canada and the United States edited by Alexander Moens and Martin Collacott, 53-74. Toronto: Fraser Institute.

Golovetskky, Basil. 2006. "Are Cross-Border Movements and Border Security Complements." Vancouver Centre for Excellence Research on Immigration and Integration in the Metropolis Working Paper Series No. 06-21.

Hawkins, Freda. 1975. "Canada's Green Paper on Immigration Policy." International Migration Review Vol. 9, No. 2: 237-249.

Immigration and Refugee Board of Canada. 2011. "The Immigration and Refugee Board of Canada Does..." Last Modified November 17. Accessed June 4, 2012. http://www.irbcisr.gc.ca/Eng/media/info/Pages/does.aspx.

Immigration Legislative Review. 1998. Not Just Numbers: A Canadian Framework for Future Immigration. Ottawa: Government of Canada. Accessed March 10, 2012. http://www.chba.ca/uploads/Policy\%20Archive/1998/1998-02-28.pdf.

Inge, Joseph R. and Findley, Eric A. 2006. "North American Defense and Security after 9/11". JFQ Forum Issue 40, 1st Quarter: 23-28.

Interview with anonymous 1, March 8, 2012

Keeble, Edna. 2005. "Immigration, civil liberties, and national/homeland security." International Journal, Spring, Vol. 60, No. 2: 359-372.

Kelley, Ninette and Treilcock, Michael. 2010. The Making of the Mosaic A History of Canadian Immigration Policy. Toronto: University of Toronto Press.

Kislenko, Arne. 2010. "Guarding the Border: Intelligence and Law Enforcement in Canada's Immigration System" in The Oxford Handbook of National Security and Intelligence, edited by Johnson Loch, 310-327. New York: Oxford University Press.

La, John. 2004. “Forced Remittance in Canada's Tamil Enclaves.” Peace Review 16:3: 379-385.

Leuprecht, Christian. 2012. "Security Implication of Demographic Change" in Evolving Transnational Threats and Border Security: A New Research Agenda, edited by Christian Leuprecht et al., 39-50. Kingston: Center for International and Defense Policy, Queen's University.

Macklin, Audrey. 2009. "Refugee Roulette in the Canadian Casino" in Refugee Roulette Disparities in Asylum Adjudication and Proposals for Reform, edited by Java Ramji-Nogales et al, 135-163. New York: New York University Press. 
Pratt, Anna. 2005. Securing Borders Detention and Deportation in Canada. Vancouver: UBC Press.

Public Safety Canada. 2004. "Securing an Open Society: Canada's National Security Policy." National Library of Canada. Accessed March 12, 2012.

http://site.ebrary.com.ezproxy.lib.ryerson.ca/lib/oculryerson/docDetail.action?doclD=1008312 $\underline{4}$.

Public Safety Canada. 2011. "Currently Listed Entities." Last Modified August 24. Accessed August 7, 2012. http://www.publicsafety.gc.ca/prg/ns/le/cle-eng.aspx\#LTTE

Roach, Kent. 2003. September 11 Consequences for Canada. Montreal: McGill-Queens University Press.

Roach, Kent. 2007. Better Late Than Never? The Canadian Parliamentary Review of the AntiTerrorism Act. Montreal: Institute for Research on Public Policy.

Rousseau, Cecile et al. 2002. "The Complexity of Determining Refugeehood: A Multidisciplinary Analysis of the Decisions Making Process of the Canadian Immigration and Refugee Board." Journal of Refugee Studies Vol. 15 No.1, 43-70.

Royal Canadian Mounted Police (RCMP). 2010. "Integrated National Security Enforcement Teams." Last Modified June 15. Accessed March 12, 2012. http://www.rcmpgrc.gc.ca/secur/insets-eisn-eng.htm.

Sedra, Mark and Burt, Geoff. 2011. "Security Sector Reform (SSR) and the DomesticInternational Security Nexus The Role of Public Safety Canada." The Centre for International Governance Innovation Special Report No.1.

Sheppard, Mary. 2012. "Refugee claims show inconsistent approval rates." CBC News, March 12. Accessed March 12, 2012. http://www.cbc.ca/news/canada/story/2012/03/12/refugee claims-show-inconsistent-approval-rates.html.

Stoffman, Daniel. 2002. Who Gets In: What's wrong with Canada's immigration program - and how to fix it. Toronto: MacFarlane Walter and Ross.

Teotonio, Isabel. 2010. "Toronto 18." The Toronto Star. Last Modified December 1. Accessed July 4, 2012. http://www3.thestar.com/static/toronto18/index.html 
Tilson, David et al. 2012. "Cutting the Queue: Reducing Canada's Immigration Backlogs and Wait Times." Standing Committee on Citizenship and Immigration, February. Accessed March 13, 2012.

http://www.parl.gc.ca/Content/HOC/Committee/411/CIMM/Reports/RP5376198/411 CIMM Rpt02 PDF/411 CIMM Rpt02-e.pdf.

Wark, Wesley. 2002. "Intelligence Requirements and Anti-Terrorism Legislation" in Security of Freedom: Essay on Canada's Anti-Terrorism Bill edited by Ronald J. Daniels et al., 287-296. Toronto: University of Toronto Press.

Wark, Wesley. 2006. National Security and Human Rights Concerns in Canada: A Survey of Eight Critical Issues in the Post-9/11 Environment. Ottawa: Canadian Human Rights Commission.

Whitaker, Reg. 2004. "Immigration Policy" in The Oxford Companion to Canadian History, Edited by Gerald Hallowell. London: Oxford University Press Reference Online. Accessed March 10, 2012. http://www.oxfordreference.com/views/ENTRY.html?subview=Main\&entry=t148.e774. 


\section{Glossary of Terms}

IRB:

RDP:

RAD:

ID:

IAD:

IRPA:

GIC:

CBSA:

Public Safety:

IIN:

INSETS:

IBETS:

CIC:

RCMP:

CSIS:

CISC:

Immigration

System:

Immigration Policy:

Refugee

(Determination)

System:

Border Security

System:

Border Security

Policy:

Border

Management:

National Security:

BRRA:
Immigration and Refugee Board

Refugee Protection Division

Refugee Appeal Division

Immigration Division

Immigration Appeals Division

Immigration and Refugee Protection Act

Governor in Council Appointees

Canada Border Service Agency

Department of Public Safety and Emergency Preparedness

Immigration Intelligence Network

Integrated National Security Enforcement Teams

Integrated Border Enforcement Teams

Citizenship and Immigration Canada

Royal Canadian Mounted Police

Canadian Security Intelligence Service

Criminal Intelligence Service of Canada

System in place for the management and selection of individuals who wish to live and work (temporarily or permanently) in Canada. Currently guided by the IRPA.

Policy of a state that governs the entrance and settlement of individuals to a country to which they are not native.

System in place that offers protection to people in Canada who fear persecution or whose removal from Canada would subject them to a danger of torture, a risk to their life or a risk of cruel and unusual treatment or punishment. Guided by the IRPA.

System and mechanisms in place guided by numerous national security policies that are meant to manage and monitor the flow of goods and people that enter and leave Canada through all ports (air, land and marine).

Measures taken by a government to monitor the transit of people across its borders, which contributes to ensuring the protection of its land and population.

The approach by border service agencies to enforce borer security policy in order to manage the flow of trade, immigration, and travel at all ports of entry (i.e. air, land and water)

Policies and mechanisms meant to ensure the safety of Canada and its population.

Balanced Refugee Reform Act 